\title{
THE "JŪDŌ SUKEBEI" PHENOMENON: WHEN CROSSING THE LINE MERITS MORE THAN SHIDŌ [MINOR INFRINGEMENT] - SEXUAL HARASSMENT AND INAPPROPRIATE BEHAVIOR IN JŪDŌ COACHES AND INSTRUCTORS
}

\author{
Carl De Crée \\ University of Rome "Tor Vergata", Rome, Italy \\ Ghent University, Ghent, Belgium \\ International Association of Judo Researchers, United Kingdom \\ E-mail: prof.cdecree@earthlink.net
}

\begin{abstract}
The sport of jūdō was intended as an activity "for all". Since in 1996 a major sex abuse scandal broke out that involved a Dutch top jüdō coach and several female elite athletes, international media have identified many more abuses. To date no scholarly studies exist that have examined the nature, extent, and consequences of these anomalies. We intend in this paper to review and analyze sexual abuses in jūdō. To do so we offer a descriptive jurisprudence overview of relevant court and disciplinary cases, followed by a qualitative-analytical approach looking at the potential factors that prompt jūdō-related bullying and sexual harassment. Sex offenders may be attracted to jüdō because of: 1. the extensive bodily contact during grappling, 2. the easy access to voyeuristic opportunities during contest weigh-ins and showering, 3. Jūdō's authoritarian and hierarchical structure as basis for 'grooming', 4. lack of integration of jūdō's core moral component in contemporary jūdō coach and instructor education, and 5. its increasing eroticization by elite jūdō athletes posing for nude calendars and media and by specialized pornographic jūdō manga and movies. Cultural conceptions and jurisprudence are factors that affect how people perceive the seriousness and how these offences are dealt with. A survey of 19 cases of abuse in jūdō worldwide shows that cultural conceptions and jurisprudence cause that such cases are handled in a very heterogeneous way by the law and by the jūdō governing bodies. Jüdō clubs and organizations overall suffer from a lack of expertise, intellectual insight, ethical objectivity, and solid procedures of fairness for both victim and accused, in this way often failing in both sufficiently protecting the weak from sex offenders, and in educating and reintegrating past offenders through jüdo activities that do not involve their victim target groups. Jūdō's moral philosophy implicitly attempts to offer a utilitarian answer as to how the jūdō community should deal with serious offences. These incidents, however, continue to show the limitations of jüdō's utopian "prosperity for all" objective.
\end{abstract}

Key words: child abuse, criminals, judo, jurisprudence, legal cases, martial arts, sexual harassment, sexual offenses. 


\section{Introduction}

In 1882 a Japanese educator by the name of Kanō Jigorō (1860-1938) created Kōdōkan $j \bar{u} d \bar{o}$ as a form of physical and mental education. Kanō formulated two maxims that formed the conceptual foundations of $j \bar{u} d \bar{o}$. Jü $\bar{c}$ 's second maxim, the one most relevant in the context of this

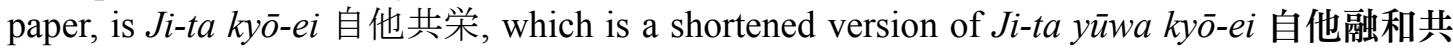
栄, which is a Confucianism-inspired principle that means "Mutual prosperity and harmony for everyone". In Kanō's view, the whole of society should be the primary beneficiary of $j \bar{u} d \bar{o}$. This should be achieved through each individual striving for the utmost morality. Even though it took 45 years before the Kōdōkan opened its first women's division (De Crée \& Jones, 2011), there is little doubt that Kanō intended jū $\bar{d} \overline{\text { to }}$ be for everyone, young and old, men and women, Japanese and non-Japanese. Therefore, the term expression "Jū $d \bar{o}$ for all" is a truism.

Over the years a number of scholars in the West have suggested that Kanō's ideas are largely utopian and unrealistic (Casado \& Villamón, 2009). From a way of life with emphasis on intellectual development and from an ethical philosophy with practical physical education component adaptable to self-defense, $j \bar{u} d \bar{o}$ has essentially been reduced to nothing but a competitive combat sport geared towards obtaining medals (Andō, 2013). Despite jū $\overline{\bar{o}}$ 's evolution or 'devolution', one thing that has never been in question in modern times is its suitability for people of all ages; at least this has never been in question 'officially'. In reality though, it does not all appear that simple.

In 2011 a scandal broke out of over a hundred $j \bar{u} d \bar{o}$-related cases of children's deaths in Japan either through negligence of coaches and instructors or because of outright child abuse. However, $j \bar{u} d \bar{o}$ has been plagued by many other serious cases of abuse, particularly those of a sexual nature, most of which have remained largely hidden from the international media until recently. We agree with Cense \& Brackenridge who have previously pointed out that recent revelations of sexual misconduct by sport coaches have challenged the population's beliefs in the educational value of sport, and that there is a necessity to increase our knowledge about the dynamics of sexual exploitation in sport and identify risk factors to serve as a basis for improvements (Cense \& Brackenridge, 2001)

The title of this paper "When crossing the line merits more than shido" "refers to a jū $\overline{\bar{o}} \mathrm{com}$ petitive rule where stepping outside of the one-meter red danger zone of a Japanese $j \bar{u} d \bar{o}$ contest tatami, used to be strictly penalized. Shidō is a jū $\bar{c} \bar{o}$ 's lightest penalty for prohibited actions or rule violations during contests. "When crossing the line" in this paper is used in its figurative meaning of improper touching, harassment or professional behavior, with the title suggesting that it is time that such sexual misbehavior is taken seriously.

Apart from a few newspaper articles and Internet gossip, an occasional blog (Ley, 1998), and a single non-peer-reviewed online paper (Buckle, 2009), there exist no scholarly papers which have reviewed and analyzed the prevalence, background and nature of sexual abuse in $j \bar{u} d \bar{o}$. We intend in this paper to review and analyze $j \bar{u} d \bar{o}$-related bullying and sexual abuse of women and children. We will also devote attention to how these issues have been dealt with by law enforcement and/

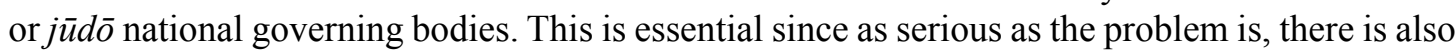
an important shadow side to it, namely the intentional use of false accusation as an expression of political power struggles or discrimination. We will also offer suggestions about how to best preventing sexual abuse and discrimination from occurring in $j \bar{u} d \bar{o}$ and how to best deal with them.

\section{Methods}

In this paper we first offer a descriptive jurisprudence overview of relevant court and disciplinary cases. Cases were located through the use of Internet search engines and legal data bases. For ethical and privacy reasons we will only elaborate on court and disciplinary cases which are already in the public domain and where the accused was found guilty by a court of law. We will then follow up with a qualititative-analytical approach to study the potential factors that may result in $j \bar{u} d \bar{o}$-related bullying and sexual harassment. 


\section{The nature and organizational framework of jūdō}

$J \bar{u} d \bar{o}$ is a contact sport. In most contact sports practitioners will have incidental bodily contact, which during competitive matches depending on the sport may be allowed or penalized. In jū $d \bar{o}$, bodily contact is not merely incidental, but sustained. During standing jū $\bar{o}$, called tachi-waza, two players have to grip each other to practice their movements; hence there is at least contact with hands and arms, which is extended to other body parts during throwing attempts. During newaza or mat work though, slow-moving sustained whole-body contact is typical. While the average jū $\bar{c} k a$ simply focuses on technique and improving him-/herself, the situation may present itself as a prime opportunity for sex offenders since these situations can be exploited by those with paraphilias such as frotteurism, who get excited by rubbing themselves up against another person's body or by 'accidentally' touching the submitted opponent in sensitive and private places. Others are not even that subtle: "On the judo mat he made grappling into an erotic game. His would stick his hand under the judo uniform and through the neck opening into your bra. Ground fighting, which normally maximally last 4 minutes, then could last 20 minutes. 'I just had to allow it, otherwise the fight would not stop', says Irene de Kok.” (...) (Van Corven, 1997).

Improper touching in locker rooms, showers and saunas have also been reported. It is in this context that we have coined the term jūdō sukebei 柔道助平 [“jūdō lecher" or "jū $d \bar{o}$ pervert"]. The word sukebei 助平 is Japanese and means 'lecher' or 'pervert'. A jū person (male or female, though usually of the male gender) who under the pretense of engaging in $j \bar{u} d \bar{o}$ and associated activities, seeks out situations to satisfy socially unacceptable sexual practices sexual desires, paraphilias or similar socially unacceptable sexual behaviors generally without the consent of the other(s), or, potentially involving minors (Figure 1).

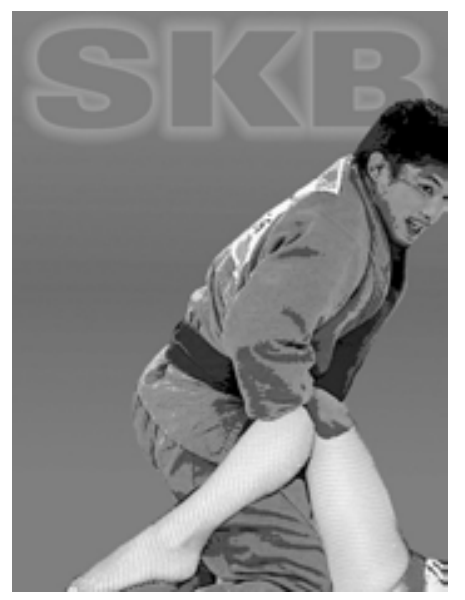

Figure 1: Poster featuring 2004 and 2008 double Olympic champion (-66 kg) Uchishiba Masato 内柴正人 in a compromising pose alluding to his arrest and subsequent conviction for rape of a female member of the Kyūshū University's jū $\overline{d o}$ team. The letters 'SKB' in the background refer to the Japanese word sukebei 助平 is Japanese and means 'lecher' or 'pervert'.

Abuses in jū $\bar{c} \bar{o}$ have not been limited to frotteurism. Bullying and harsh treatment have been part of coaching styles in Japanese martial arts. These methods go back on a Japanese principle which is called ai no muchi 愛の鞭, which means “whip of love”. Beating with bamboo sticks or kendō shinai [swords] all fit within this concept. Choking out people for fun by ignoring that they in fact first tapped out is another typical hazing technique that is often applied on young novice jūdō black belt students.

In 2007 reports emerged of a 17-year old Japanese sumō wrestler who had died after being beaten by three fellow wrestlers (Andō, 2013). This is a practice known as taibatsu 体罰 or "corporal punishment" (Whiting, 2003a, 2003b) which goes further than just ai no muchi which 
still contained a factor of genuine care or even love. Similar coaching incidents had existed in $j \bar{u} d \bar{o}$ for more than a century and so were hardly news to any jū $\bar{o} \bar{o}$ connoisseur or organization. Over the course of 2011 three high school students died as a consequence of school jūdo activities in Japan (Anonymous, 2012). In October 2011, Uchida Ryō 内田良, an associate professor at Nagoya University Graduate School of Education and Human Development, reported that at least 114 deaths in children had occurred during jū $\bar{u} \bar{o}$ practice in Japan between 1983 and 2009 in schools alone (Burke, 2010). Several of these deaths were not mere accidents but instead caused by totally inappropriate and boot camp-like training methods, which from a medical point of view were often dangerous and irresponsible.

The latest $j \bar{u} d \bar{o}$ incident involved Japan's women's $j \bar{u} d \bar{o}$ team coach Sonoda Ryūji, who decided to resign following complaints of fifteen women of Japan's 2012 Olympic women's jū $\bar{o}$ team over allegations of verbal abuse, beatings and hazing (Andō, 2013). This and a few recent high-profile cases in the media, which we will detail later in this paper, appear to represent only the tip of the iceberg of what seems to be widespread misbehavior of $j \bar{u} d \bar{o}$ coaches and instructors.

Some patterns of $j \bar{u} d \bar{o}$ coaches' professional misconduct represent far more overt forms of sexual abuse, primarily of women and of children. In 2011 the jū $\bar{o}$ world went through shock when Japan's 2004 and 2008 double Olympic champion in his role as a women's team coach (Brasor, 2011; Westlake, 2012) was arrested, whilst over the past years jiūdo enthusiasts have also learnt how the United States' most recent (female) world and first Olympic champion (Baxter, 2012; Forgrave, 2012) was a victim of a sexual abuse by her coach. This illustrates that sexual abuses in $j \bar{u} d \bar{o}$ occur at a highest sports levels.

Many more cases are either documented or have been suspected though. The first European Women's $J \bar{u} d \bar{o}$ Championships took place in the form of a try-out in 1974 in Genoa, Italy. It is from around that time that countries started forming national women's jū $\bar{o}$ team and in the absence of experienced women's coaches, virtually all of those teams ended up under the guidance of senior male jū $\bar{o} k a$, often 15-30 years older than the athletes in the team. Suspicions have been around for decades that many of these coaches abused their position. According to Bringer et al., (2006) $1 / 5^{\text {th }}$ out of 266 respondents in Canadian Olympians had engaged in sexual intercourse with an authority figure in sport (coach, instructor, or official)! Hence the number of less far-going sex acts between athletes and coaches is presumably even much higher, particularly in a sport such a $j \bar{u} d \bar{o}$ with frequent and continued bodily contact. In the past, sexual favors were often demanded of female $j \bar{u} d \bar{o}$ athletes who were hoping for national team selection. Young female jū $d \bar{o} k a$, often from lower social backgrounds or with modest results in school that did not exactly predict stellar professional careers, were often 'groomed' by their coach through a combination of harsh physical training and psychological terror. In this way, the coach or instructor attempted to install a certain dependency in them: "casser le moral" [breaking their mental strength and resistance] through exhaustive physical training and high demands, alternated with praise and hugs when their athletes did well in competition, represented a typical approach in coaches with ulterior motives (Forgrave, 2012; Holden, 2012). Consequently, many women would go very far just to please their male coach. This is how ai no muchi or "the whip of love" oftentimes was or is literally turned into acts of sexual gratification.

Looking back, many of those female athletes active in the late 1970s and early 1980s have ended up getting married to their coach, with the question lingering when such sexual relationships actually started and whether when they started they were still minors and in violation of applicable law. In any case, for most $j \bar{u} d \bar{o}$ federations and law enforcement agencies the issue has become moot so many years later, and perhaps that is the best way too, but the issue nevertheless remains of the utmost importance to draw lessons from and prevent future sexual abuse of anyone in $j \bar{u} d \bar{o}$, female or male, young or old.

According to Fasting et al., (2002) who obtained data from 27 Norwegian female elite athletes through questionnaires and personal interviews, most commonly reported experiences were "repeated unwanted sexually suggestive glances, jokes, comments, etc."(27), "unwanted physical contact" (22), and "ridicule" (21); in addition to these three major categories of harassment, "threatening sexual suggestions, proposals etc. (8)", "stalking" (3), "humiliating treatment" (2), "flashing" (2) and "rape or attempted rape" (1) were also reported (Fasting et al., 2002). No similar 
studies have been done in $j \bar{u} d \bar{o}$ athletes, and the only relevant information available comes from news reports and disciplinary or court cases. Presumably, these represent only some of the most serious cases that involve law enforcement or lead to major public scandals. However, the stories of these athletes and description of these cases may shed light on other aberrant and preparatory behaviors that may have preceded, followed or accompanied those major cases. At the least they will help indicating certain disturbing patterns.

\section{Incidence and jurisprudence of cases of sexual abuse in jūdō}

A thorough search by means of Internet search engines, jurisprudence and jūdo data bases resulted in the identification of 19 cases of abuses of a sexual or violent nature that are in the public domain and that have led to criminal convictions and/or disciplinary procedures. These cases are:

1. The Peter Ooms case - Dutch Judo Federation (JBN), The Netherlands, 1996 (Anonymous, 2009b; Van Corven, 1997; Van Der Ziel, 1996; Van Wissen, 1996a, 1996b)

2. The Richard van Deun case - Dutch Judo Federation (JBN), Amsterdam, the Netherlands, 2004 (Anonymous, 2004a, 2004b; Endedijk \& Van Steenbergen, 2012)

3. The Emilio 'Mel' H. Augustine case - United States Judo Federation (USJF), US, 2004/2005 (Svinth, 2001; USDOJ, 2012)

4. The Sylvain Hébert case - Judo Québec \& Judo Canada, Varennes, Québec, Canada, 2006 (Anonymous, 2006; Dussault, 2006; Pilon, 2005)

5. The Alvin Miyatake case - United States Judo Federation (USJF)/USA Judo (USJI), US, 2006/2007 (Curtis, 2009)

6. The Doyle/Harrison case - USA Judo (USJI), Dayton, Ohio, US, 2007 (Anonymous, 2007b, 2007c, 2007d, 2007e; Baxter, 2012; Cazeneuve, 2012; Ensslin, 2010; FBI, 2008; Forgrave, 2012; Holden, 2012)

7. The Leyton Dodge case - Welsh Judo Federation \& British Judo Association (BJA), Wales, United Kingdom, 2008 (BBC News, 2008)

8. The Fletcher Thornton case - United States Olympic Committee (USOC), USA Judo (Anderson, 2008; Rodriguez, 2009; Thamel, 2008a) (USJI) \& United States Judo Federation (USJF), Middletown, California, USA, 2009

9. The Adler Volmar case - USA Judo/USJI, Colorado Springs, CO, USA, 2008 (Ennslin, 2010a, 2010b; Gomez, 2011)

10. The Ryan Rebman case - USA Judo/USJI, New York City, NY, and Livermore, CA, CO, USA, 2009/2011 (Anonymous, 2009c; The Associated Press, 2012; Thissen, 2012)

11. The Wolfgang Doffek case - Bavarian Judo Federation (Bayerischer Judo-Verband e.V.) and German Judo Federation (DJB), Passau, Lower Bavaria, Germany, 2009 (Anonymous, 2009a; Landgericht Passau, 2009; Lauver, 2011)

12. The David G. Leonard case - United States Judo Association (USJA), Yuba City, California, USA, 2009 (McCarthy, 2009a, 2009b; The People vs. David Gerald Leonard, 2011)

13. The Curtis B. Rogers case - United States Judo Association (USJA), Pawtucket, Rhode Island, USA, 2011 (Caligiuri, 2011; Rhode Island State Police, 2011; Towne, 2012)

14. The Joop ter Heegde case - Dutch Judo Federation (JBN), Rotterdam, the Netherlands, 2011 (De Havensloods, 2011; Verspeek 2011, 2012b, 2012c)

15. The Uchishiba Masato case - All Japan Jūdō Federation (ZNJR) \& Kyūshū University of Nursing and Social Welfare, Kyūshū, Japan, 2011 (Associated Press 2013; Brasor, 2011; Japanese Ministry of Justice, 2007; Jiji Press, 2013; Westlake, 2012)

16. The Alan Roberts case - Dartford Judo Club \& British Judo Association (BJA), United Kingdom, 2012 (Buckler, 2012) 
17. The Rajiv Arora case - Judo Camp Sundernagar, Himachal, India \& British Judo Association (BJA), India, 2012 (Parshad, 2012)

18. The Leo Buitink case - Dutch Judo Federation (JBN), Ruurlo, the Netherlands, 2012 (Anonymous, 2013; De Stentor, 2012)

19. The Sonoda Ryūji case - All Japan Jūdō Federation (AJJF), Tōkyō, Japan, 2013 (Andō, 2013; McCury, 2013; The Japan Times Editorials 2013)

At least one more, widely published, high-profile case involving a former double Olympic $j \bar{u} d \bar{o}$ champion (1984 and 1986) currently remains under investigation by judicial authorities (Anonymous, 2014). We will now further elaborate on the most significant of these cases.

\section{The Peter Ooms case - Dutch Judo Federation (JBN), The Netherlands, 1996}

In February 1996, Anita Staps, the first Dutch world champion women's jū $\bar{c} \bar{o}$ (New York 1980, -61 kg weight category), presented her (then) new book: "Judo belts". The Dutch and international media immediately showed great interest, but not so much for the sportive achievements of Staps, by then long retired from active competitive $j \bar{u} d \bar{o}$. Instead something else caught the attention of the journalists. In her book, Staps revealed years of sexual abuse by former Dutch national women's jū $\overline{\bar{o}}$ coach Peter Ooms.

Staps had joined Ooms' jūdō school when she was 7 years old. At Ooms' school she had experienced a spiral of success, fear and dependency. Anita Staps decided to "come out and tell", because she anticipated a repetition of the same facts in Tilburg. Staps pointed out: "Ooms allowed himself took every possible liberty except the last one". Perhaps that was where he put his own limit was (Van Wissen, 1996a). Staps does not want Ooms to run around in jū $\bar{c} \bar{o}$ training halls after 20 years still remaining unpunished (Van Der Ziel, 1996; Van Wissen, 1996a, 1996b).

According to Staps: "As a child you are an easy prey. Ooms demanded absolute obedience and you gave in, because he did everything for you and because at the same time he also was successful in obtaining results. He would almost literally use a whip on you. I remember a small rubber police baton which he used almost in a funny way. I regularly had bruises. But at such moments you don't realize the actual mistreatment." (...) (Van Wissen, 1996a).

Anita Staps suspected that coach Peter Ooms acted from a "deeply rooted" inferiority complex which caused him to attempt putting his pupils in a relationship of dependency (Van Wissen, 1996a). Anita Staps: "There was no sense is arguing. You are young and dependent. You are afraid that jūdō will stop. So you allow intimacies which you do not really want. Ooms will probably also have his version; any story has two sides to it, but he has crossed the line. He determined everything, I was his possession and that is what he used." (...) (Van Wissen, 1996a)

Ooms' other famous jū $\bar{o}$ champions Monique van der Lee and Irene de Kok also experienced sexual harassment from Ooms and with Staps filed a joined complaint with the Dutch Jü $\bar{o}$ Federation (Van Der Ziel, 1996; Van Wissen, 1996a, 1996b).

Van der Lee in Staps' book describes her experiences during the 1995 women's jū $\bar{c} \bar{o}$ world championships as follows: "In my head I was more fighting him [= Ooms] than my opponents. I really did not like staying in my hotel room because doing so meant he would come in to cuddle. $J \bar{u} d \bar{o}$ is a contact sport, but everyone understands that this does not mean putting your hand in someone's bra or getting into bed with you and rubbing yourself up against someone.” (...) (Van Wissen, 1996a) (Figure 2) 


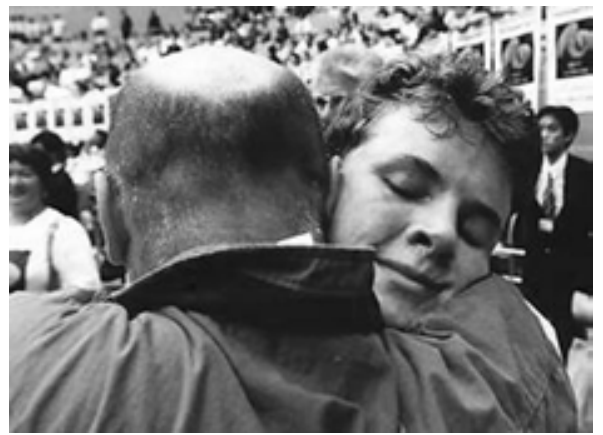

Figure 2: Dutch former world champion (Open class) and 4-time European champion (three times Open, once $+72 \mathrm{~kg}$ ) Monique van der Lee with success coach Peter Ooms, later (1997) found guilty and convicted by the Breda Court for inappropriate behavior towards his female athletes.

Irene de Kok, the 1986 and 1987 women's jūdō world champion wrote: "I thought that Ooms' touching was part of it. Furthermore, I was winning and that is what mattered to me." (...) (Anonymous, 2009b)

The statements by the three female jūdōka in Anita Staps' book were followed up by interviews in a documentary broadcast on the Luxemburg national TV station RTL4, in which the three women provided more details about precisely what actions took place (Van Wissen, 1996b).

Ooms reacted by stating that he would indeed have had a sexual relationship with Staps, but only after she was 18 years old, not 15 . He also admitted during some foreign trips having slept in the same bed as de Kok in order to save money, with de Kok having been his choice because she was lesbian and therefore his interest not of a sexual nature (Van Wissen, 1996b). According to Ooms, the women would have had an interest in forcing him to give up his leadership positions. De Kok would have been preparing starting up her own school while still being an employee in Ooms' school and wanted to be released. Van der Lee's father reportedly had attempted to blackmail Ooms for 40,000 Dutch guilders $(€ 18,511)$ in order to have his daughter "not tell" (Van Corven, 1997; Van Wissen, 1996b).

Ooms added that: "As I have come to realize much to my regret, my manner of interacting with the jüdōka involved has led to problems, and I have concluded this if I would be able to do everything over, I would act in a different way. " (...) (Van Wissen, 1996b)

Ooms also pointed out that touching is part of $j \bar{u} d \bar{o}$ and a coach/pupil relationship is characterized by a dominant role played by the coach. How else can one engage in top sport and produce world champions ? (Van Corven, 1997; Van Wissen, 1996b) Ooms was indeed extremely successful as a coach, via his jū $\bar{c} \bar{k} a$ obtaining not less than four world titles, ten European titles, and 130 Dutch national champions (Van Wissen, 1996b).

Since Ooms spontaneously resigned his functions, the Dutch Judo Federation (JBN) did not take them away, but a disciplinary committee of the JBN did suspend Ooms for three years (Van Der Ziel, 1996). However, in July 1997 the Court in Breda, The Netherlands, convicted Ooms to four months of probation, while he was also for three years denied to exert any function in $j \bar{u} d \bar{o}$ (Anonymous, 2009b; Van Corven, 1997). Although on August $9^{\text {th }}, 1997$ Ooms announced he would appeal the penalty, he withdrew the appeal about a week later (August $15^{\text {th }}$ ). Instead, Ooms chose to provide his version of the facts in a book published at the end of August 1997 (Anonymous, 2009b).

\section{The Doyle/Harrison case - USA Judo (USJI), Dayton, Ohio, US, 2007}

Probably the most high-profile $j \bar{u} d \bar{o}$ sex abuse case to hit the news since the 1996 Peter Ooms case in the Netherlands was the "Doyle/Harrison case". Since at the time when the matter broke out Kayla Harrison was still a minor her name was kept out of the news (Anonymous, 2007b, 2007c, 2007d, 2007e; Ensslin, 2010; FBI, 2008). However, later Harrison chose to disclose the 
story history herself without concealing her identity and talked about it publicly to several newspapers hence how the case later became known under her name (Baxter, 2012; Cazeneuve, 2012; Forgrave, 2012). Since Harrison in August 2012 became the first ever American Olympic jū $\bar{c} \bar{o}$ champion her story as a victim of sexual abuse by her former coach was widely taken up by the media (Holden, 2012).

Harrison was introduced to $j \bar{u} d \bar{o}$ after following her mother, a black belt, into the gym when she was 6 years old. Harrison progressed quickly and by age 8 she had joined the elite Renshüden Jüdō Academy in Centerville, $\mathrm{OH}$, where she met Daniel Doyle, the club's junior coach and also the owner's son who was 16 years her senior. Doyle quickly became a trusted family friend, babysitting Harrison and her two siblings, and accompanying them on vacations and hosting sleepovers at his home. Doyle was a successful coach coaching Harrison to two national titles before her $15^{\text {th }}$ birthday. Harrison became so victorious that she partook in international jū $\bar{c} \bar{o}$ contests for juveniles and Doyle as her coach would chaperone the girl to several international tournaments in Estonia, Russia, and Venezuela (Anonymous, 2007e; Baxter, 2012; Cazeneuve, 2012; FBI, 2008; Forgrave, 2012)

It turned out that Doyle had started a sexual relationship with Harrison when she had just turned 13 years, with sexual inappropriate actions taking place on several occasions between August 2003 and April 2007 both in the US and during foreign trips (Anonymous, 2007d, 2007e; FBI, 2008; USDOJ, 2007). Whilst most countries have no jurisdiction to incidents that took place outside its territorial borders except for a few limited cases of extreme malice, such as, for example, crimes against humanity, US law does allow prosecution of sex crimes committed by an American against an American even when outside of US territory. Doyle also videotaped their sexual activities on at least one occasion (FBI, 2008). Years of 'grooming' by her jū $\bar{o}$ coach, had turned Harrison into an ideal sex-abuse victim, i.e., someone who both loved and feared him perceiving him as a volatile, demanding coach, and who would everything to please him.

After Harrison finally confided in a $j \bar{u} d \bar{o}$ friend, who subsequently disclosed the details to Harrison's mother, the latter immediately contacted police who would promptly arrest Harrison's coach. Doyle eventually pled guilty and was given a 10-year prison sentence. Doyle was also asked by the court to surrender all video-making equipment, videos and pictures containing the Harrison's image. Doyle was also required to register as a federal sexual offender after he will have completed his time in prison. He was also expelled for life by USA Judo. A database search of the US Department of Justice Sex Offender's Registry yields a positive return for Doyle (USDOJ, 2012). The case gained particular notoriety because Harrison in 2010 in Tōkyō, just a few years after Doyle's conviction, became the United States' first female world jū $\bar{o}$ champion (category $-78 \mathrm{~kg}$ ) since AnnMaria Burns (now AnnMaria De Mars) had preceded her in 1984 (category -56 $\mathrm{kg}$ ). In an interview, Harrison talks about the complex emotions she went through at the time of Doyle's arrest and after (Baxter, 2012; Cazeneuve, 2012; Forgrave, 2012). She indicated that she felt awful when Doyle was arrested, and was continuously confronted with the painful details when the news was on $\mathrm{CNN}$ and when $j \bar{u} d \bar{o}$ chat forums on the Internet debated what Harrison's role was, some considering her as an innocent victim, some considering as partly guilty. She talked about those conflicting emotions when she watched her old coach get sentenced to 10 years in prison. One has to consider that to Harrison this was the same man that Harrison for years had assumed she would marry after she turned 18. "It was bittersweet. It was definitely closure. I needed to get up in front of the judge and him and say my piece. I explained to the judge that what once was my passion (jūdō) is now my prison. It was the toughest day of my life. It was heart-wrenching. I did not know what to feel, and that made it worse. Everyone was so happy, so excited. Everybody had been so angry for so long. To everyone else, that was the end. They could move on with their lives. But it wasn't that easy for me. I cried pretty much every night." (Forgrave, 2012)

According to newspaper interviews Harrison also considered suicide for some time, and wrote about it in her diary, but (luckily) never acted on it. Very much in the sense of the classical "American Dream" kind of story, the case has been of great attraction to journalists and the general public fond of tragedies turned into success. This became even more so when in 2012 when Harrison became the first American Olympic jū $\bar{c} \bar{o}$ champion ever. While Harrison's world and Olympic titles no doubt are a crown rewarding her years of devotion to hard jū $\bar{o} \bar{o}$ training, one 
also cannot but notice that though in 2005 she competed in the $-57 \mathrm{~kg}$ class (e.g., het 2005 silver in the Pan-American juvenile championships) she moved up not less than three weight categories in very short time and became a $-78 \mathrm{~kg}$ player. Even though physical maturation no doubt plays a natural role in this process, a $20 \mathrm{~kg}$ (almost lbs. 45) gain in body mass in just three years time for a young female athlete is very substantial and reminiscent of the eating disorders that are frequent among female jū $\bar{c} \bar{k} a$.

\section{The Adler Volmar case - USA Judo/USJI, Colorado Springs, CO, USA, 2008}

On September $28^{\text {th }}, 2008$, an incident occurred at the Antlers Hotel in Colorado Springs, CO, involving a girl who was 15 at the time and US Olympic jū $\bar{u} \bar{o}$ team member of Haitian origin, Adler Volmar, aged 33 yrs. Volmar was accused of trying to force the girl to perform oral sex on him, and prosecutors argued that when she refused, he pushed her on her back on his bed, and then raped her (Ensslin, 2010b). The incident occurred after a wild night in which the girl, described as a tomboy had snuck into a night club with the suggestive name "Sodo Night Club" through a back door, after employees initially had turned her away suspecting her to be underage. At the night club the girl consume at least six alcoholic drinks in celebration of a jū $\overline{\bar{o}} \bar{o}$ tournament which had taken place earlier that day. According to prosecutors, the girl suffered tears and abrasions to her vagina, and bled for a week after the incident (Ensslin, 2010a, 2010b).

Despite these being the facts as how they were originally represented, several questions were raised during the trial about the veracity of how the story was represented, questions, some of which remained without a satisfactory answer. For example, it was noted that the girl did not report the incident to police and did not go to the hospital until the following morning. She then flew to Montreal a few days later, and on to Thailand. This course of events surprised the defense who did not find this a likely scenario for girl or woman who had just undergone a major trauma. Furthermore, the defense wondered why she went back to Volmar's room when she had a key to her own room in her back pocket. It was also argued that argued that the sex was consensual and that the girl had sex with Volmar after taking a shower there at $02: 30 \mathrm{~h}$ and coming out of the bathroom wearing nothing but a towel (Ensslin, 2010b).

The prosecution counter-argued: "The fact the girl was 'sloppy drunk' is irrelevant. She is telling Volmar 'no'. She is pushing. But what happens? Nothing. It keeps going. ... Why not stop ? Because Volmar would not let her. Does this sound like an encounter between two (consenting) adults inside a hotel room ? Does it sound like that ?" (...) (Ensslin, 2010b)

The Volmar case is different in several aspects from many other cases involving sexually illicit behavior in the sense that Volmar was not the instructor or coach of the girl, even though, no doubt, as someone 16 years her senior, he likely did exert a dominant role. The case was also complicated by the girl 6 months before the end of the trial suddenly claiming to prosecutors that in fact she was a lesbian (Ensslin, 2010b), a statement which apparently was intended to support why she never would have given any consent to having sex with Volmar. The existence of a such an important detail known all the time to the girl, but disclosed by her only at a late stage and perceived by the defense as an attempt to influence the outcome of the trial, raised considerable questions; in fact, Volmar's defense attorneys would also call into question the girl's sexual orientation.

In October 2010 a jury acquitted Volmar of the rape charge finding him not guilty of felony sexual assault of the girl. However, the jury did find Volmar guilty of two misdemeanor counts of having oral sex with a juvenile who was at least 10 years younger. Volmar would also be required to register as a sex offender as a result of the misdemeanor convictions. Following this decision, Volmar remained free on bond and was allowed to return home pending the sentencing hearing (Ensslin, 2010a). On February $8^{\text {th }}$ of 2011, Volmar was sentenced by $4^{\text {th }}$ Judicial District Judge David A. Gilbert to 60 days in the El Paso County jail in Colorado. He also was required to undergo five years of supervised probation, ordered to register as a sex offender and instructed to not engage with anyone under 18 (Gomez, 2011). Volmar's victim was reported being medicated and having been in therapy for nightmares and suicidal thoughts since the encounter with Volmar (Gomez, 2011). Consequently, the parents of the girl have filed a civil lawsuit against Volmar and USA Judo, which according to newspapers, was meant with the purpose of recouping expenses for her 
therapy. Volmar was also expelled for life by USA Judo. A database search of the US Department of Justice Sex Offender's Registry yields a positive return for Volmar (USDOJ, 2012).

\section{The Ryan Rebman case - USA Judo/USJI, New York City, NY, and Livermore, CA, CO, USA, 2009/2011}

In March 2009 an alleged incident happened in a hotel in New York City. Ryan Rebman (29 yrs. old) from Livermore, CA, the 2004 California jū $d \bar{o}$ coach of the year and a jū $\bar{o}$ instructor there in his father's club, the Amador Judo and Jujitsu Studio and at Studio Advertisement Quantcast, was accused of having sodomized one of his female students (Anonymous, 2009c). The assault took place in New York City while the teenage girl was staying in a hotel with Rebmann, her instructor, and chaperone for the night for a layover for their flight to the Dominican Republic where the group was heading to participate in a competition (Anonymous, 2009c). The girl reported the incident after she returned. A New York magistrate issued a warrant for Rebmann's arrest on the charge of forcible sodomy, a $3^{\text {rd }}$ class $\mathrm{E}$ felony, after which he was arrested by Livermore and New York detectives at his hometown in Livermore, CA (Anonymous, 2009c). On May $28^{\text {th }}, 2009$, Rebmann was arrested and incarcerated in the Vernon C. Bain Correctional Center in New York (Anonymous, 2009c). On September 16 ${ }^{\text {th }}, 2009$ at the Queens Supreme Court in New York, Rebmann pled guilty on the charge of a criminal sexual act in the third degree. Rebmann was sentenced to 5 months in jail, 10 years of probation, and was classified as a level-1 sex offender (Anonymous, 2009c).

On Oct. $20^{\text {th }}, 2011$, Rebmann at that time 31 years old was arrested again, now in Pleasanton, CA, on suspicion of having had sex with a 15 -year-old girl between June $1^{\text {st }}$ and Aug. $14^{\text {th }}$. Rebmann was charged with six counts of unlawful sex with the girl, six counts of lewd and lascivious acts on a child and one count of attempting to escape from custody for allegedly trying to flee the Livermore police station when he was arrested (The Associated Press, 2012; Thissen, 2012). Rebmann pleaded no contest and had been expected to get three years in stat prison, which was indeed the sentence that was imposed on him on July $9^{\text {th }}, 2012$ (Jordan, 2012). Rebmann will be eligible for parole a year and a half later but will be held from release pending the resolution of his case in New York, where he is now also facing up to seven years in jail for violating probation in the previous 2009 sex crime conviction in that state (The Associated Press, 2012; Thissen, 2012). The plea deal also required Rebmann to register as a sex offender for the rest of his life (The Associated Press; 2012, Thissen, 2012). In addition, Rebmann was also already expelled for life in 2009 by USA Judo and the two other main jū $\bar{o}$ organizations in the United States.

\section{The Wolfgang Doffek case - Bavarian Judo Federation (Bayerischer Judo-Verband e.V.) and German Judo Federation (DJB), Passau, Lower Bavaria, Germany, 2009}

The President of the Bavarian Judo Federation for the first time heard about Wolfgang Doffek, a jū $\bar{o}$ instructor and decade-long president of the 1. Judoverein Passau [First Passau $J \bar{u} d \bar{o}$ Club] following a complaint about inappropriate behavior with children in December 2003 (Laufer, 2011). However, no evidence was found that sufficed to build a case on against Doffek. Thus Doffek stayed in function and continued his work (Laufer, 2011). One of the rumors most frequently heard, was that of Doffek after practice showering with the kids and enthusiastically soaping in their bodies (Laufer, 2011). However, in 2008 following new complaints, this time from the mother of two of his students about three incidences of inappropriate touching, Doffek denied and kept insisting he was simply teaching proper hygiene to his pupils (Laufer, 2011). However, the Ambtsgericht [Court] of Passau on August $3^{\text {rd }}$ of 2008 nevertheless found that the charges were sufficiently proven and convicts Doffek to 10 months of probation (Landgericht Passau, 2009; Laufer, 2011). Doffek decided to appeal the penalty.

Nevertheless, it turns out that Doffek simply returned to his $j \bar{u} d \bar{o}$ club and continued to shower with and soap the bodies of the kids (Laufer, 2011). Doffek continued to remain popular with both the kids and most parents. He is highly intelligent and has been said to have an IQ of 145. He was helpful to the socially and financially most challenged parents and easily gains their trust (Laufer, 2011). Afterwards many understood that Doffek simply preyed on the weakest of society. For 
example, he offered to help out a divorced single mom and moved into her house. But at night he started visiting her son in his bedroom to engage in inappropriate sexual activities (Laufer, 2011).

In April 2009 after new complaints to the Bavarian Judo Federation about the then 38-year old Doffek who allegedly continued to shower with the kids, the president of the federation contacts police (Laufer, 2011). Finally a victim of Doffek decided to come forward. German law enforcement decided to open a new investigation and discovers that nine young victims aged 9-15 year had been sexually abused by Doffek over a 15-year period, starting in 1994 and lasting until 2009. Police counted 211 incidences of inappropriate touching and other sexual acts with children. Doffek realized that his appeal now had little chance of being successful and decided to withdraw it. German police on April 22 $2^{\text {nd }}$ of 2009 arrested Doffek and charged him with multiple sex offences against children (Anonymous, 2009a, 2010; Landgericht Passau, 2009).

On January $8^{\text {th }}$ of 2010 the Landgericht (District Court) Passau found Doffek guilty of multiple incidents of sexual abuse of children and sentenced him to 6 years and 9 months in prison (Anonymous, 2010) (Figure 3). Because Doffek was considered a high-risk pedophile with likely recurrence and little chance of recovery, he was also sentenced to indefinite psychiatric internment. Not only the German jū $\bar{o} \bar{o}$ world but the entire German sports world is shocked by the duration and extent of the abuse and several committees are formed to discuss and implement new measures to prevent such criminal behavior from reoccurring and from going on undetected (Laufer, 2011).

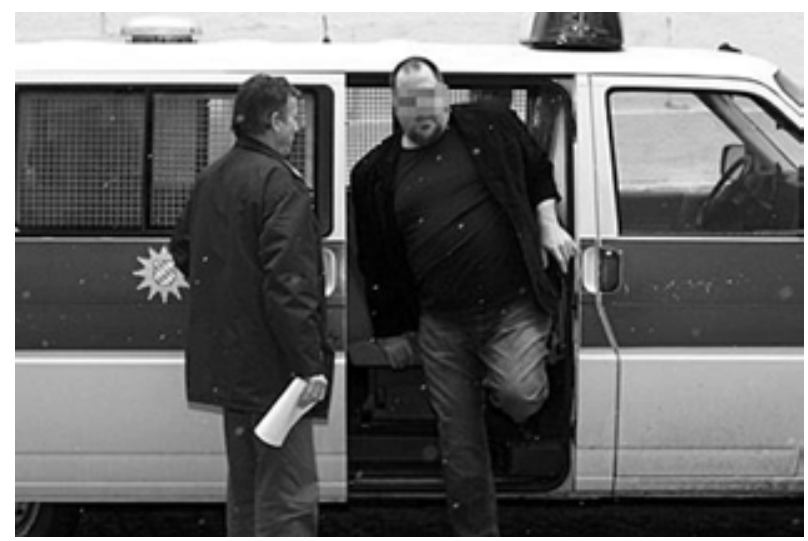

Figure 3: German sex offender Wolfgang Doffek found guilty in 2010 by the Passau District Court of multiple incidents of sexual abuse of children and sentenced to 6 years and 9 months in prison, and subsequent psychiatric confinement.

The Curtis B. Rogers case - United States Judo Association (USJA), Pawtucket, Rhode Island, USA, 2011

On June 22 ${ }^{\text {nd }}, 2011$, the Rhode Island State Police (RISP) Computer Crimes Unit (CCU)/ Internet Crimes Against Children (ICAC) Task Force, along with the West Warwick Police Department, arrested Curtis B. Rogers, age 37, for five (5) counts of 1st Degree Sexual Assault, four (4) counts of $1^{\text {st }}$ Degree Child Molestation and one (1) count of $3^{\text {rd }}$ Degree Sexual Assault (Rhode Island State Police, 2011). Previously the parent of a 15-year old boy had contacted police filing a criminal complaint against Rogers who allegedly had sexually assaulted the boy as well as two of his friends. Rogers had access to the children through his role as a youth football coach in Pawtucket, RI, and through his volunteer work as a jūdo instructor at the Coventry Judo Club. An investigation was conducted, which led to additional victims being identified. Upon his arrest and upon continuation of the investigation even more victims were identified, which resulted in additional charges being brought against Rogers. Some time after, Rogers wife, Crystal Rogers, 29, was also arrested and charged on three (later increased to six) counts of third-degree sexual assault of minors (Caligiuri, 2011). Both Rogers and his wife are arraigned in Providence Superior Court on multiple child sex counts. 
The crimes took place between November 2007 and June 2011. Some of the victims of Curtis Rogers were under the age of 14, and some of the victims of Crystal Rogers were under the age of 16. A total of at least eight victims came forward (Caligiuri, 2011). The penalties for conviction on the above offenses under the applicable law ranged from not less than ten years to life in prison (Rhode Island State Police, 2011). Rogers pleaded guilty and on July $25^{\text {th }}$ of 2012 the Providence Superior Court sentenced him to 50 years in prison with 25 to serve, on charges of child molestation and sexual assault (Towne, 2012). His wife was sentenced to five years with one to serve, after pleading guilty to three counts of third-degree sexual assault. She was accused of engaging in sexual activity with three boys between the ages of 14 and 16 (Towne, 2012). Both also had to register as sex offenders. At the time of writing, a database search of the US Department of Justice Sex Offender's Registry yields a positive return only for Rogers' wife.

\section{The Joop ter Heegde case - Dutch Judo Federation (JBN), Rotterdam, the Netherlands, 2011}

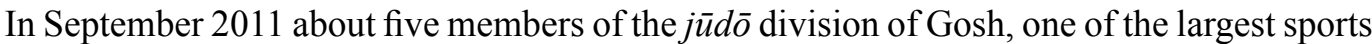
and health clubs in Rotterdam South, have filed criminal complaints for sexual harassment and molestation against ter Heegde, age 58 at that moment, who is a current co-owner of the club, but who until 2002 also was one of their jū $\bar{o}$ instructors (De Havensloods, 2011). All of the alleged victims were male. The offences took place in The Netherlands and abroad (France and Spain) between 1994 and 1998. It was alleged that during stay-overs sleeping bags would be zipped together while ter Heegde liked to spoon with the children, and inappropriately touched them. He was also alleged to have French-kissed the children under the pretense of "showing love towards each other". Furthermore, he allegedly injected one 12-year old boy with liquid soap in his anus supposedly because "enemas are often used to achieve rapid weight loss prior to competition" (De Havensloods, 2011).

However, several people have also raised doubts about the veracity of the accusations suggesting they might be of malicious origin and have been organized by a faction associated with a 29-year old business partner of the suspect within the school; the suspect allegedly used to be in a relationship with that business partner (Verspeek, 2011, 2012b). The detention of ter Heegde had been extended several times. On March $8^{\text {th }}, 2012$, it was reported that ter Heegde had been released without bond. The outcome of the case and the truthfulness of the allegations initially remained unclear, especially after psychiatrists have been unable to detect any personality disorders, deviating behavior, or pedophile patterns in his thinking or interests; neither did the suspect have a prior criminal record, nor any previous complaints of pedophilia against him (Verspeek, 2012b).

According to the district attorney: "It started with cuddling, followed by a kiss, then touching and at a given moment a hand would go down their pants. The abuse has been carefully crafted" (Verspeek, 2012c). Evidence consisted of five people who had filed criminal complaints, seven additional compromising statements, sexually explicit letters and text messages, and nude pictures of two adolescent male members of his $j \bar{u} d \bar{o}$ club which were found on Ter Heegde's computer (Verspeek, 2012c).

On July $11^{\text {th }}$, 2012, a Rotterdam judge found Ter Heegde guilty and sentenced him to 3 years in prison of which 27 months effective and 9 months on probation, two years of mandatory therapy for sex offenders, and punitive damages of $€ 7,500$ to each of his three victims. The judge commented that: "The accused for years systematically abused young boys who believed they were free from voyeuristic attention at the club or during camps abroad. It went from cuddling and hugging to acts of lewdness. Oftentimes these involved boys who were in difficult situations at home" (Verspeek, 2012a).

The judge found no indications of false accusations of a conspiracy being at work (Verspeek, 2012a). However, the court also found, however, that not all charges were proven, in particular those which involved sexual encounters between adults without coercion (Verspeek, 2012a). In addition, sexual encounters between the instructor and his pupils which took place abroad in countries where such is not against the law neither could not be prosecuted. Awaiting a possible appeal the judge allowed Ter Heegde to remain free since it involved old facts. Despite recommendations from behavioral psychologists that Ter Heegde no longer be active as a judo teacher, 
the court set aside these objections concluding that doing so would have implied the closure of Ter Heegde's jū $\bar{c}$ school and additional loss of jobs, and that Ter Heegde was not a pedophile (De Havensloods, 2012).

\section{The Uchishiba Masato case - All Japan Jūdō Federation (ZNJR) \& Kyūshü University of Nurs- ing and Social Welfare, Kyūshū, Japan, 2011}

On December $6^{\text {th }}$ of 2011, Uchishiba Masato 内柴正人, Japan's 2004 and 2008 Olympic Champion in the $-66 \mathrm{~kg}$ weight class and most recently coach of Kyūshū University's jūjdo team, was arrested by the Tōkyō Metropolitan Police Department on suspicion of raping a female team member. The victim, a minor, went out drinking with the rest of the Kyūshū University of Nursing and Social Welfare's $j \bar{u} d \bar{o}$ team and their coach, Uchishiba, one night in September after a training session in Tōkyō. A female member of the team, at the time 19 years old ended up very drunk while at a Karaoke bar, and Uchishiba volunteered to take her back to their hotel in Hachiōji 八王子, where the alleged rape took place. Uchishiba, 34 years old and married with children, admitted the two had sex but insists that the act was consensual (Brasor, 2011). Prosecutors alleged that Uchishiba woke up and became aware of what was happening, but that he turned up the volume on the television and used his hand to cover her mouth (Westlake, 2012). Uchishiba was promptly fired as a jū $\bar{\jmath} \bar{o}$ coach by his university in September already over allegations of sexual harassment, and in January 2012 was also barred from all competitions by the All Japan Jūdō Federation. Uchishiba was quickly arrested and locked up in jail with requests for bail having repeatedly been denied.

To avoid confusion in the understanding of this case, the age of consent in Japan is 13 yrs., and one is allowed to enter the adult industry or legally work as a prostitute at age 18 yrs. (Penal Code, art. 34). The Japanese Penal Code, article 177, adds: "A person who, through violence or intimidation, has sexual intercourse with a female person of not less than thirteen (13) years of age commits the crime of rape and shall be punished with imprisonment at forced labor for a limited term of not less than two years. The same shall apply to a person who has sexual intercourse with a female person under thirteen (13) years of age.” (...) (Japanese Ministry of Justice, 2007)

However, despite the age of consent being 13 years, the age of majority is 20 years (Japanese Penal Code, art. 3), which in Japan means that you cannot legally drink alcohol until you are 20 yrs. old despite having been allowed to engage in sex for years ( $\geq 13 \mathrm{yrs})$, even commercially $(\geq 18$ yrs). In other words, "age of majority" in Japan does not equal "age of consent" (...) (Japanese Ministry of Justice, 2007). The prohibition on alcohol under age 20 is also not typically enforced if it happens at home or under supervision of a parent. It is one of those laws that can be and is often arbitrarily enforced. Japan has considered since 2005 or 2006 to lower the age of majority from 20 to 18 mainly for voting reasons, but this has not yet happened.

Furthermore, some prefectures in Japan have restrictions that can be explained as that age of consent locally being increased to 16 or 18 years even though the Japanese Constitution says otherwise. In such cases the accused may still be punished despite what the Constitution says, even though strictly speaking, consensual sex with someone over 13 years of age in Japan is only prosecutable if the prosecution can prove that the other person, presumably adult in this case, either 'forced', 'threatened' or 'drugged' (for example by intentionally making the other person drunk) the person of $>13$ yrs (Penal Code, art. 178) (...) (Japanese Ministry of Justice, 2007).

On December $28^{\text {th }}, 2012$, it was reported that prosecutors would be seeking a 5 -year jail term for Uchishiba (Westlake, 2012). On February $1^{\text {st }}$ of 2013 the Tōkyō District Court found Uchishiba guilty of rape and jailed him for 5 years (Associated Press, 2013, Jiji Press, 2013, Westlake, 2013). The presiding judge added that: "Actions that are aimed only at satisfying lust are malicious", and that "Uchishiba had repeatedly used unreasonable excuses and showed no remorse." (Jiji Press, 2013). Uchishiba is expected to appeal (Associated Press, 2013).

\section{The Leo Buitink case - Dutch Judo Federation (JBN), Ruurlo, the Netherlands, 2012}

On October $9^{\text {th }}$ of 2012 Police arrested Leo Buitink, a 52-year old jū $\bar{o}$ instructor of the Judo Club Leo Buitink in Ruurlo, The Netherlands, after two jū $\bar{c} \bar{o}$ students had filed criminal complaints 
for sexually inappropriate conduct referring to once incident that had occurred in 1999 and other incidents that had taken placed between 2009-2011 (De Stentor, 2012). A third complaint was filed by a family member with regard to conduct that had taken place ten years earlier when the woman was still a minor (De Stentor, 2012). The Dutch Judo Federation (JBN) suspended the jū $\overline{\bar{o}}$ instructor awaiting the outcome of the police investigation (De Stentor, 2012). The Prosecution demanded 4 years in prison of which 3 years to be served. On 2012, the District Court in Zutphen found Buitink guilty of molestation of his eldest daughter and of having sexually abused one of his $j \bar{u} d \bar{o}$ students during a vacation in France, and sentenced him to 3 years in jail with 2 years to serve (Anonymous, 2013). He was acquitted of three other counts because of a lack of evidence. Because the acts themselves did not take place during or immediately before or after $j \bar{u} d \bar{o}$ classes or while acting as a jū $\bar{o} \bar{o}$ instructor, Buitink was allowed to continue working as a jū $\bar{u} \bar{o}$ instructor (Anonymous, 2013).

\section{The Sonoda Ryūji case - All Japan Jüdō Federation (AJJF), Tōkyō, Japan, 2013}

On February $15^{\text {th }}, 2013$, Japanese women's $j \bar{u} d \bar{o}$ coach Sonoda Ryūji 園田隆二 resigned after the international press reported accusations that he physically abused members of Japan's women's jū $\bar{d} \bar{o}$ team in the buildup to the 2012 London Olympics. Although no acts of lewdness were reported, fifteen of his athletes had sent a letter of complaint to the Japanese Olympic Committee (JOC) alleging that they had been bullied and slapped by Sonoda and other coaches, beaten with a bamboo kendō shinai [sword], and forced to compete while injured (McCurry, 2013). The AJJF reprimanded Mr. Sonoda and the other coaches, but Japan's sport minister was not satisfied with that and ordered the JOC to conduct a full investigation.

The Guardian reported that police would also investigate the case (McCurry, 2013). Four days after head coach Sonoda had resigned, he was followed by assistant coach Tokuno Kazuhiko, and by Yoshimura Kazuo 吉村和郎, the AJJF's Athlete Development Director (The Japan Times Editorials, 2013). Yoshimura previously had an excellent record as a men's jū $\bar{o}$ coach. However, in a typical anti-intellectualist $j \bar{u} d \bar{o}$ approach instead of approaching training in a rational and scientific way, he overemphasized the importance of willpower. In doing so he had in the past forced injured $j \bar{u} d \bar{o}$ athletes to take part in matches and also had imposed extremely heavy training schedules. With the Japanese men's team over the last few years not living up to expectations, a new training approach was tried out in the men's national team with Yoshimura's approach no being longer welcome. This put him in an awkward position in consequence of which he started frequenting the women's jū $\bar{o}$ practices instead where his harsh approaches to training soon became the standard.

The results of the investigation by the JOC were released on March $17^{\text {th }}, 2013$. After interviewing the women for 20 hours and their seven coaches for 17 hours, JOC concluded that head coach Sonoda was a sadist, who would make personal insulting comments such as calling the women 'pigs' and mocking them as 'ugly' (Anonymous, 2013a). The assistant coach, Tokuno Kazuhiko, was reported, while practicing mat techniques with one woman, to have covered her mouth while dangling a dead insect around her body to scare her (Anonymous, 2013a). On March $20^{\text {th }}, 2013$, the JOC announced that serious misconduct had occurred, in consequence of which it issued thirteen directives to the AJJF: "The directives include prohibition of violence or misconduct directed at athletes by coaches, the establishment of a framework for athletes to communicate concerns to the organization's decision makers, clear and transparent procedures for selection of national team members, and the increased hiring of women as coaches and AJJF executives. The Executive Board also decided to cut the AJJF's annual subsidy for team development in the fiscal year starting next month" (...) (Anonymous, 2013c). Furthermore, the JOC set up a system for the anonymous reporting of any violence, harassment or misconduct in sports administered by Japan's national federations (Anonymous, 2013c).

Only after the international press had become aware of what was going on, the International Judo Federation quickly released a rambling statement disapproving of such bullying behavior, and emphasizing its commitment to maintain the health and integrity of the participants. It added that anything that went against these principles is banned and that they would therefore "take all necessary measures" (McCurry, 2013). This statement was somewhat bizarre as it suggested that 
$j \bar{u} d \bar{o}$ 's main organization would not be aware of these coaching techniques which otherwise are

Former women's jū $\bar{d} \bar{o}$ world champion (1984) Yamaguchi Kaori, who currently is an associate professor at the University of Tsukuba University Graduate School and former coach of her university's women's jū $\bar{c} \bar{o}$ team, counseled the abused athletes and supported them when they came out with their allegations. Yamaguchi commented: "People like Sonoda are under pressure to win gold medals, so their thinking reverted to the "jutsu" [martial technique] for combat. They lost the educational element. We could also hire non-Japanese coaches. The keywords are 'respect' and 'open-mindedness.' It's important for us to start by respecting opponents, be they strong or weak, and to open up the organization and take in a diversity of opinions" (Andō, 2013).

\section{Potential legal problems and consequences for the internationally and interstate-active jūdōka}

Other authors have previously highlighted that attitudes of coaches towards being intimate with athletes are lax, and that both athletes and coaches generally have poor knowledge of the relevant laws and regulations (Toftegaard Nielsen, 2001). We note that among the cases of sexual misconduct we reviewed some situations which involved people acting with the other's consent, such as those who were merely in violation of laws of statutory rape without necessarily having any criminal intent. Such mere neglect of ignorance of the law could have devastating effects for the jū $\bar{c} k a$ involved found in violation of the law. For example, it could very well be that two jū $\bar{o} k a$ have a loving relationship, intend to get married and have consensual sex one week before the person reaches the minimal age allowed by law for sexual relations. Even if a law in general may serve society best - which is not necessarily always so- it does seem that a rule utilitarian interpretation and application would have been able to serve both society and this couple in an optimal way.

This poses all kinds of new problems. For example, jūdō's philosophy, in particular, ji-ta kyō-ei or "prosperity for all of society" is intended as universal across different cultures and nations, but laws mostly are not. The age of consent is not universal at all. In Japan, $j \bar{u} d \bar{o}$ 's country of origin, the age of consent is 13 years (Japanese Ministry of Justice, 2013), as it is in South-Korea, an age which is much lower than in most European countries, the US, or Australia. In most European countries it is 16 years, with only a few significant exceptions (18 years in Malta and Turkey, and only 13 years in Spain). In the US, it is 16 years in most states and in Puerto Rico, but 17 in Colorado, Illinois, Louisiana, Missouri, Nebraska, New Mexico, New York, Texas, Wyoming, and even 18 years in Arizona, California, Delaware, Florida, Idaho, North Dakota, Oregon, Tennessee, Utah, Virginia, Wisconsin, Pennsylvania.

However, many States in the United States have complicated exceptions that increase the age of consent or even disregard consent in situations where a person is in a position of authority. Specifically, Connecticut, Kentucky, Maryland, Minnesota, New Hampshire, New Jersey, Ohio, Vermont, and Washington increase the age from 16 to 18 years if one person has a position of authority towards the other; New Mexico increases it from 17 to 18 years, and Alabama even from 16 to 19 years. Both Connecticut and Kentucky state law specify the role of the coach as one of those positions of authority. The others generally do not, but often refer to teacher/school, and courts may consider a jū $\overline{\bar{o}}$ club as a kind of school. Texas prohibits all sexual contact between a school employee and a student irrespective of the age of the student, unless the two are legally married. It is unclear whether this statute could be extended to a jū $\bar{o}$ club, its instructors and 'students'.

Particularly, the American laws may pose a complex situation for coaches and jū $\bar{c} k a$ who frequently may be travelling across state borders or those who may need to reside in states with thoroughly different laws regarding sexual cohabitation. For example, in Alabama the age of consent is 16 years, but is lifted to 19 years if one person is a school employee. These constraints may apply to someone who may be in a loving relationship with a consenting partner while both mistakenly might believe they meet the minimal age of consent, whilst in reality due to some exception in the law they may be in violation of the law. For example, a 20 -year old jū $\bar{o}$ instructor engaged to be married to an 18.5-year old jüdōka whose home state is DC. They have been having sexual 
relationships for 6 months in their home state. They travel to Alabama and sleep together. They are aware that the age of consent in Alabama is 16 years just like it is in their home state, thus they are convinced they are acting entirely according to the law. In reality the 20 -year old could be arrested for statutory rape and be required to register as a sex offender for the rest of his life.

\section{Cultural divide and perceptions of age disparity in sexual relationships}

Cultural perception of sexual behaviors by youngsters also appears to be fundamentally different. At the American side of the pond the entire jū $\bar{u}$ public gets outraged if a person of 17 years, 11 months and 51 weeks in a state where the legal age is 18 , has consensual sex with someone who is older. Prosecutors may demand the 'offender' to be sentenced by penalties at the European side other side of the pond solely seen in heinous crimes such as murder. Voices and posts on American Internet forums go as far as to demand that the 'offender' be executed on the spot. American Jū $\bar{o}$ federations hasten to expel the 'criminal' if necessary, with complete disregard of due process, respect for the rights of the defense or their own statutes. The extent of the cultural divide was clearly illustrated in December 2007, when European media learnt that then 27-year old Belgian professional cyclist and 2005 World Champion elite men's road race Tom 'Tommeke' Boonen turned out to be in a relationship with 16-year old Dutch Sophie van Vliet, whom Boonen got acquainted to in 2005 when van Vliet was still 14 years old (Anonymous, 2007a, 2008). Even though the European media devoted ample attention to their relationship and the jokes were not out of the air, the general public was generally supportive of their relationship mostly concluding it was nobody else's business. Certainly the kind of tone of general public outrage with copious expressions of extremely negative appreciation in the sense such as "child rape", "sexual predators" and "settling the matter with a bullet between his eyes", which is typically observed in American media when confronted with a sexual relationships between a 16-year old and a 27-year old, were nowhere to be heard. Also the idea that European law enforcement would step in was completely unimaginable, as the affair was consensual and none of those involved had any reason to file any criminal complaint. Pretty much in such cases European law enforcement and courts tend to consider the spirit of statutory rape laws rather than the letter. It is often argued that likely it was not the intention of the lawmaker to cause irreparable personal and professional future in a consensual and relatively stable relationship where one of the partners may not have mathematically reached the age of consent, but is very close to doing so, is rather an adolescent than a child, is of an age that likely the majority of people these days already have sexual encounters, and there is no situation of force or illegitimate means in the sense of physical threat or use of drugs or alcohol. This approach is different from the American approach where there is no reluctance to call someone a "child rapist" even if this 'child' is a 17- or even 19-year old who has been driving a car for years, has held a job, lives by her/himself, may have years earlier reached the minimal age for marriage, and has independently and consensually chosen to engage in sexual with a person, but merely may be some calendar time short of the official legal age of consent.

Complicating the consequences of sexual interaction between athletes below the age of majority or between an athlete and coach is the fact that United States law may have extraterritorial provisions. In the Doyle/Harrison case, Doyle and Harrison were both US citizens and engaged in sexual relations when Harrison was between 14-17 years old (both were from Ohio where the age of consent is 16 years) on three foreign trips (Estonia, Russia, Venezuela) (FBI, 2007; USDOJ, 2007). However, the age of consent in Estonia is 14 years. Normally, a citizen visiting a foreign country is subject to local laws, as the territorial limitations of his own country have no bearing on another sovereign state. Nevertheless, extra-territorial provisions in US law allowed the US to still prosecute Doyle for the behavior he displayed towards Harrison despite the sovereignty of Estonia to adjudicate its laws on acts having taken place within its territory (FBI, 2007; USDOJ, 2007).

In Canada, the age of consent is 16 , but is increased to 18 if one person is in a position of authority or the act involves sodomy. In most of Australia and in New Zealand the age of consent is 16 years; it is, however 17 years in South-Australia and Tasmania. In addition, if one of the 
people involved is in a position of authority, the age of consent for the other is increased to 18 years in New South Wales, Northern Territory, Queensland, South-Australia, Victoria and Western Australia, and in New Zealand.

In addition, Australia has extra-territorial law in that it can prosecute Australian citizens who have sex abroad with someone below the age of 16 years! The age of consent in Japan is 13 years, hence an Australian citizen 19 years old having consensual sex in Japan with someone 15 years old would act legally in Japan, but would be in violation of Australian law.

In most South-American countries the age of consent is 14 years, but with restrictions that usually have to do with violence, threat or prostitution; age of consent without restrictions is therefore generally 18 years in most South-American countries.

Age of consent in many middle eastern Muslim countries may be different for men than for women, and sometimes illegal if outside of marriage (Iran, Kuwait, Oman, Pakistan, Qatar, Saudi-Arabia, UAE); some of these, such as, for example, Saudi-Arabia, have no minimal age for getting married and thus for consent.

Apart from the problem that age of consent is not universal across states, nations and cultures it even is not constant within the same country or culture. For example, the 1971 movie Summer of ' 42 became the sixth highest-grossing film of that year and one of the most successful films in history with an expense-to-profit ration of 1:32 and with an additional estimated more than $\$ 20$ million from subsequent video rentals and purchases (Figure 4). The film also attracted wide acclaim after being broadcast on major television channels across the world. Furthermore, the book became one of the best selling novels of the first half of the 1970s, requiring 23 reprints between 1971 and 1974 to keep up with customer demand (Anonymous, 2002).

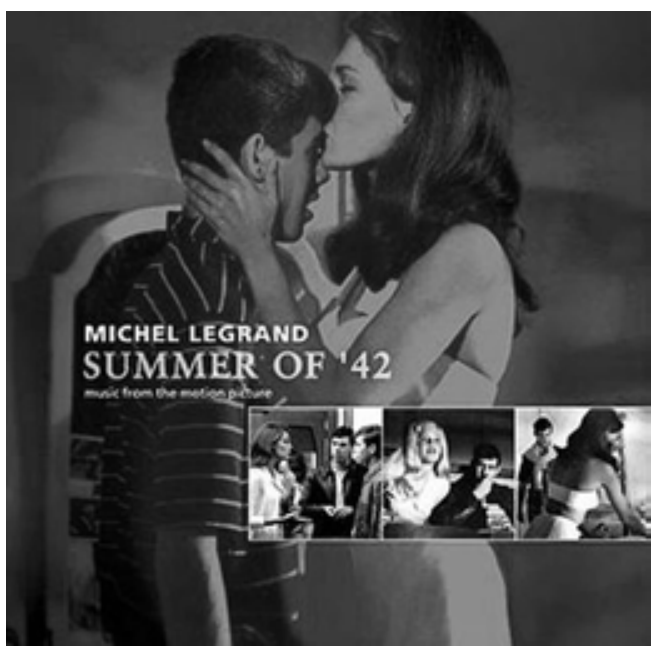

Figure 4: Movie poster of Michelle Legrand's Summer of ' 42 a film which famously portrayed the romance of a 15-year old boy with an adult woman, which was widely applauded back in 1971.

The film written by and based on the memoirs of Herman Raucher is a coming-of-age drama that reflects his experiences as a 14-year old boy during the summer of 1942 spent on Nantucket Island (Anonymous, 2002). The story is about the young boy (he is depicted in the movie as being 15 years old rather than 14) embarking on a romance with an adult woman whose husband had gone off to fight in World War II (Anonymous, 2002). Despite the clear age difference between the two protagonists, and the boy being underage, the film was universally praised, and never attracted a major wave of protest or concerns because of statutory rape. In fact, the movie by many was perceived almost as an ideal ... "introduction into adult life" ...

Famous movies such as The Graduate (1967), Paris Texas (1984), American Beauty (1999), Autumn in New York (2000), Manhattan (1979), Gigi (1958), Wish you were here (1987), Limelight (1952), Der Blaue Engel (1930), The Misfits (1961), Harold and Maude (1971), Breakfast at Tif- 
fany's (1961), Last Tango in Paris (1972), Jane Eyre (1944), Bitter Moon (1992), Le Mari de la Coiffeuse (1990), Malizia (1973), and at least 200 more major movies depict and glorify sexual relationships in couples composed of people with considerable age disparity.

Numerous other works of art have idealized similar sexual relationships that if carried out in reality legally would be in violation of strict US statutory rape laws, such as for example, Meg Rosoff's How I live now, another war-time story, this time of 15-year old Daisy, who is being sent off from Manhattan to England to visit her aunt and cousins she had never met before.

In some, the younger partner clearly is of legal age, but in many others they are young adolescents. Most of these movies, books and other works of art clearly distinguish themselves though from others that glorify outright pedophilia, such as the famous 1955 Vladimir Nabokov novel Lolita. Despite the illegal nature of such relationships in many countries Nabokov's controversial book remains one of the most popular and highly praised of all times, although admittedly, this probably also has to do with his literary qualities of his writing style (e.g., his characteristic use of synesthetic detail). Another example is the 1912 novella by Thomas Mann Der Tod in Venedig, perhaps even more famous through the 1971 Luchino Visconti movie Death in Venice with Dirk Bogarde. Contrary to the other examples, this movie almost idealizes a more-than-just-Platonic relationship of a homosexual nature between an older man who feels attracted to a young boy. Even though the two never talk, less even touch, the relationship is considered almost as if it were part of a work of art, without any suggestion of immorality or illegal paraphilias.

The experiences, desires, and popularity of these works of art illustrate the tension and sometimes even discrepancy that exist when compared to the legal restrictions on consensual sex close to minimal legal age limits as these are defined within different cultures.

\section{Does jüdō attract sexual perverts and pedophiles?}

Sexual desires produce a very powerful drive in living beings. People with aberrant sexual desires towards children and underage people seek out their company in both leisure and professional activities, so that they can maximize the chances for selecting potential victims (Brackenridge, 1997, 2000, 2002, 2008; Brackenridge et al., no date [a], Brackenridge et al., no date [b], Bringer et al., 2001, 2002, 2006; EFSP 2002; Fasting \& Brackenridge 2009; Fasting et al., 2009, 2010; IOC 2007, 2011; Kirby et al., 2000). Popular jobs are Boy Scout leaders, camp counselors, day care workers, teachers, priests and other religious professions, school bus drivers, sports coaches and instructors, and various paramedical professions (Cense \& Brackenridge, 2001; Connolly and Marshall, 1989; Hall \& Hall, 2007; Lenskyj, 1992; NSVRC, 2005; Toftegaard Nielsen, 2001; Weiss, 2002; Wright Dziech \& Winer, 1990). All these jobs provide a guaranteed presence of the offenders' target audience. In addition, these jobs often create situations where the potential future victim needs to initiate contact either when seeking their assistance. These jobs often cause a future victim to take the offender into confidence regarding some personal problem, while the latter exerts a position of authority over the future victim. Sports are particularly interesting activities for people with aberrant sexual desires since sports may provide an opportunity to watch or work out with the victim exposing larger areas of their bodies than during most daily activities, as well as additional opportunities to witness their nudity in changing rooms (Figure 5) or when taking showers after practice. 


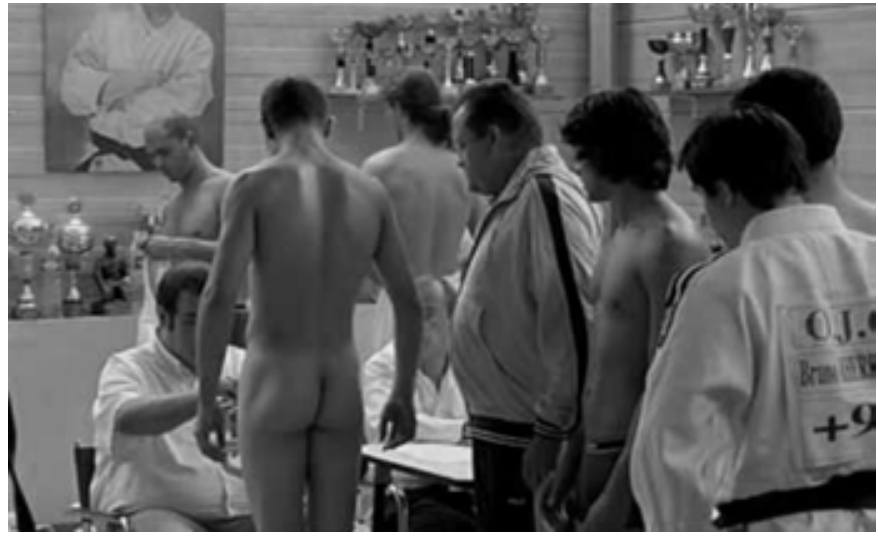

Figure 5: $\quad$ Typical scene during a jūdō weigh-in with some young jūdōka completely nude, while having little or no privacy, and oftentimes with coaches from other teams present as well as other jūdōka waiting to be weighed, and unnecessary officials potentially gratifying voyeuristic desires under the veil of fulfilling some official duty. Scene depicted taken from the French movie Douches Froides [Cold Showers].

As explained in the beginning of this paper, there have been and there continue to be significant cases of sexual indecencies and harassment in $j \bar{u} d \bar{o}$, but does $j \bar{u} d \bar{o}$ particularly attract pedophiles ? No. The notion that $j \bar{u} d \bar{o}$ particularly attracts pedophiles is wrong. Very few sex offenders in $j \bar{u} d \bar{o}$ are true pedophiles. One of the problems is that in a contemporary context a large part of the American public seems to have started to wrongfully refer to people who are in violation of an age statutory limit while engaging in sexual activities and who get arrested, as pedophiles. Doing so is quite absurd. A teacher in Alabama who has illegal sex with an 18-year old has violated state statutory rape regulations, but has in no may committed any act reflective of any pedophile inclinations. This is because the term pedophilia is commonly, but increasingly incorrectly used to refer to any sexual interest in minors below the legal age of consent, regardless of their level of mental, physical, or psychological development or maturity (Hall \& Hall, 2007). A pedophile, however, has a preference of prepubescent children, not at all for children who simply do not meet the age of consent. In fact, of the about 20 cases we reviewed in this article, barely three involve true pedophiles. Most cases involve ephebophilia and hebephilia rather than pedophilia. Ephebophiles have a strong preference for mid-to-late adolescent sexual partners (about 14-19 years old), while hebephiles sexually prefer earlier pubescent individuals.

\section{Jūdō's authoritarian and hierarchical structure as a basis for 'grooming' by bullies and sex offenders}

Organized $j \bar{u} d \bar{o}$ has its own very hierarchical power and governing structures. As in each power structure mechanisms are at work that through politics and discrimination attempt to manipulate and perpetuate who is in charge and who is excluded from power. However, it goes even further than this through the involvement of criminal activity where $j \bar{u} d \bar{o}$ or its network is being actively used as a vehicle for discriminatory and criminal intent or to gain access to innocent subjects for sexual gratification. Harsh coaching and instructing styles are common in Japanese martial arts. That can hardly be surprising. You do not typically create fighters by using a gentle touch. Instead, the boot camp-type approach or what is termed in Japanese ai no muchi 愛の鞭 [whip of love] or even taibatsu 体罰 [corporal punishment] are common practice. The logical question to follow is then whether the use of harsh training methods always amounts to abuse or at what point it crosses the line. For example, is at occasions striking an elite jū $\overline{\bar{o}}$ athlete with a bamboo stick or kendō shinai [bamboo sword] or choking him/her out as part of his/her training process synonym with abuse? 
Before answering that question, it is appropriate to consider the scarce (Western) research into $j \bar{u} d \bar{o}$ coaching styles, particularly with regard to female $j \bar{u} d \bar{o} k a$. d'Arripe-Longueville and coauthors have investigated the perceived effectiveness of coaching styles used by expert French $j \bar{u} d \bar{o}$ coaches in elite female $j \bar{u} d \bar{o}$ athletes (d'Arripe-Longueville et al., 1998). Qualitative data analyses revealed that the style with which the coaches interacted with their athletes was authoritative and generally applied in accordance with six types of strategies: (1) displaying indifference, (2) verbally provoking athletes, (3) stimulating interpersonal rivalry, (4) entering into direct conflict, (5) developing specific team cohesion, and (6) showing preferences. In other words, the proportion taken up by negative facilitation over positive facilitation seems to be fairly prevalent in coaching elite female jū $\bar{o} k a$.

That being said, the perceived autonomy, i.e. the main interaction style of athletes, was generally positive and was expressed by the following five strategies: achieving exceptional performance, diversifying information sources, showing diplomacy, soliciting coaches directly, and bypassing conventional rules. In other words, despite some considerable negative facilitation from the coaches' point of view, the coaching styles resulted in effective interactions and demonstrated the compatibility of particular interactions between coaches' and athletes' strategies (d'ArripeLongueville et al., 1998).

You could say that those various coaching strategies contain all kinds of 'unpleasant' things that may not immediately fit within Kanō's educational approach, but that do from a medalwinning point of view. After all, intentionally exhibiting favoritism and displaying an intentional disinterest in athletes are not your typical educational approaches. Yet, these strategies all have their role and 'can' be effective although they all collide with the friendly, caring stereotype one likes to depict of a jūido sensei or coach. One also has to consider local culture and values and how such approaches would be perceived. Imagine such a coaching approach in an American cultural setting. Title IX, political correctness, and potential massive class action and other law suits that could be provoked by coaching approaches which are considered atypical or unacceptable within American culture may affect how Americans will perceive them. It is not merely a matter of good $v s$. evil coaching strategies, but one of culturally accepted $v s$. not culturally accepted. Culture will affect how both outsiders and athletes perceive coaching strategies. If an athlete does not mind or believes in the effectiveness of being hit with a bamboo stick and voluntarily accepts this approach, then you can hardly speak of abuse. That picture does, however, completely change when the same coach attempts to apply the same approach to another athlete who does not accept such an approach. The French female athletes in the study by d'Arripe Longueville et al. (1998) found the negative facilitations acceptable as shown by excellent results and their willingness to accept them, whereas the Japanese female athletes in the Sonoda case (Andō, 2013; Anonymous, 2013a; McCurry, 2013; The Japan Times Editorials, 2013) clearly did not accept the coaching approach. The absence of such willingness to accept and the coach's unresponsiveness to the athletes' nonacceptance implies that the athletes' personal integrity is violated by those coaching methods being sustained despite the athletes' protest.

However, as serious and unacceptable inappropriate coaching methods may be, at the same time what we are now seeing in Japan at the same time is also a scapegoat exercise. An emotional outburst is leading to one or a handful of coaches losing their job, being branded sadists (rightly or not rightly so) and a Japanese and world audience that supposedly is looking with shock and horror at the coaches' approach whereas in reality the problem goes much deeper and is not new at all. Therefore, to make it look as that these coaches did something outlandish that has not been previously known or seen in jū $\bar{u} \bar{o}$ is distorting the truth. That certainly does not mean that these approaches should continue to be condoned, but it does call for a more thorough analysis. Instead what we saw (Andō, 2013; Anonymous, 2013a; McCurry, 2013; The Japan Times Editorials, 2013) was more an action of "who can we blame, and quickly get it over with, and give the impression we are as shocked as everyone else, so that our bid for the next Olympics is as little affected as possible by all this?"” 


\section{Gender construction in jūdō interactions}

Gender hierarchies are generally enforced in sports. The first successful female sport pioneers in typically male sports, such as, for example, Mildred E. 'Babe' Didrikson Zacharias (1911-1956), an American woman of Norwegian descent who excelled in basketball and golf, and who was one of the first to break the traditional sociological role model of femininity, faced these problems all of the time (Cayleff, 1995). A turning point in jū $\bar{o}$ was when American Rena 'Rusty' Glickman Kanokogi (1935-2009) in 1959 competed at the YMCA judo championship in Utica, New York, disguised as a man by having cut her hair short and having taped in her breasts. She was replacing an injured male team member. When Kanokogi won from her male opponent and it became known that she was a woman, she was disqualified and stripped of her medal.

Physical and sexual abuses in $j \bar{u} d \bar{o}$ are a function of power relations and are therefore not dissociated from the reinforcement of gender hierarchy in $j \bar{u} d \bar{o}$. Studies on the construction of gender differences in $j \bar{u} d \bar{o}$ or martial arts are very scarce. However, Guérandel \& Mennesson (2007) analyzed social relations and interactions in $j \bar{u} d \bar{o}$ in order to understand how jū $\bar{c} k a$ at the same

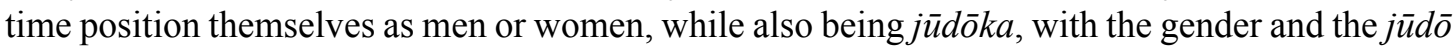
framework representing two different paradigms. These paradigms are represented by the differentiated behaviors that take place in adversarial situations (= during jū $\bar{o}$ randori [practice fight], shiai [official competitive fights] or fighting in general) $v s$. non-adversarial situations (= all other $j \bar{u} d \bar{o}$ training and social interactions including practicing technique, warm-ups, bowing, changing room activity, common travel, mat-side conversations, etc.) (Guérandel \& Mennesson, 2007).

Jūdōka during randori fights mostly interpret situations through their gender-framing experience, although sometimes the $j \bar{u} d \bar{o}$ framework takes over. Social roles are not biologically determined but the result of social construction, systematically ranking the masculine and the feminine. Women involved in traditionally masculine sports have to deal with the paradox of being a woman and having to conform to an image of femininity and 'normal' heterosexual behavior, while needing to be successful as an accomplished athlete in an environment created by and for men (Guérandel \& Mennesson, 2007). According to Guérandel \& Mennesson, " Jū $d \bar{o}$ corresponds to the playing out of a euphemized version of genuine combat" based on sporting rules such as formal equality between fighters. However, when male/female interactions occur in $j \bar{u} d \bar{o}$ this sporting and $j \bar{u} d \bar{o}$ framework comes into conflict with the framework of gender experience in the social world (Guérandel \& Mennesson, 2007).

This is at least how the situation is in modern day jū $\bar{c} \bar{o}$ as practiced in the Western world. This tension between jū $\bar{o}$ and social framework was far less present in traditional jūdō in Japan. Gender roles in $j \bar{u} d \bar{o}$ in Japan were far more a reflection of gender hierarchy in society. Female jū $\bar{o} k a$ trained at the Kōdōkan joshi-bu [Kōdōkan women's division] and their activities were separate from those of males. Female $j \bar{u} d \bar{o}$ belts corresponding to rank were, and in Japan still are, indicated by a horizontal white stripe on the belt, and promotion tests were different from those of males. Until the late 1970s Japanese women did not participate in international women's $j \bar{u} d \bar{o}$ competitions. This has all changed mostly under influence of Western-inspired feminism, international exchanges, and the fact that Japan did not want to stay behind when foreign women started claiming technical superiority in international $j \bar{u} d \bar{o}$ contests, such as especially the Olympics where women's $j \bar{u} d \bar{o}$ was introduced in 1988, initially as a demonstration sport.

Before and after training and during breaks, female and male jū $\bar{c} k a$ act differently and in accordance with sexual stereotypes (Guérandel \& Mennesson, 2007). Female jū $\bar{c} k a$ display classic signs of femininity with regard to attention to hair rearranging hair after fights or training, attention to clothes, and conversations that take place among female jū $\bar{o} k a$ (about boys, clothes) are distinctively different from those among male jū $d \bar{o} k a$ (primarily about their $j \bar{u} d \bar{o}$ performance, also about other sports such as soccer, cycling, etc.) (Guérandel \& Mennesson, 2007). Separation of sexes is reinforced through separate changing rooms, with women as "objects of sexual desires hiding their bodies in their private space represented by their changing rooms" while males, particularly in Western countries, and particularly those who know they look very fit, often change near the tatami in full view of everyone (Guérandel \& Mennesson, 2007). Gender effects are even 


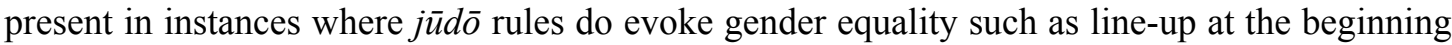
or end of a training session. Jū $\bar{o} k a$ are then arranged according to rank. However, among those of the equal rank women tend to take up the sitting positions towards the lower rank side, with males taking up the sides towards the higher ranks (Guérandel \& Mennesson, 2007). Both genders stereotypically act like this without there being any rule dictating or expecting such.

Female interaction with males during jūdo raises the question of managing relations to their body. Through gripping the jū $\bar{c} g i[j \bar{u} d \bar{o}$ uniform] much closer physical relations occur and are sustained than which most women would normally tolerate in social interactions with strangers (Guérandel \& Mennesson, 2007). Gender strategies also exist in the choice of a male or female partner during workouts, with some jū $\bar{o} k a$ avoiding the other gender. Differences in physical strength often serve as justification for the hierarchic order of males vs. females in society. Males who are 'gentle' display respect and are thus saved from losing face, whereas the women evoke that power superiority of the male (Guérandel \& Mennesson, 2007). In either coaching or mixed fighting, the social order of interaction is preserved as long as men maintain dominant position in conformity with the process of incorporating the gender hierarchy. Problems hence only arise when roles would become reversed. If males lose from females, or when a male coach's female team is unsuccessful, the male fighter or coach socially loses face.

As long the $j \bar{u} d \bar{o}$ framework prevails, manifestations of gender differences are often limited. This is more so in newaza [grappling] than in tachi-waza [standing fights], more so in kata [predetermined choreographic forms] than in randori, and more so in very intense physical fights where the male if sufficiently close to losing may feel forced to abandon his respect for sexual norms that normally governs interaction between males/females and instead devote all of his attention to the confrontation itself (Guérandel \& Mennesson, 2007). Physically or sexually abusive behaviors by male coaches and instructors towards female and children submit the $j \bar{u} d \bar{o}$ equality framework to that of the social gender or age framework so that only the social framework remains with the masculine gender factor being in absolute dominance. Voluntary participation by jū $\bar{c} k a$ in eroticization of $j \bar{u} d \bar{o}$ via sensual pictures or movies actively contributes to annihilating $j \bar{u} d \bar{o}$ 's equality framework and having it absorbed by sexual and social gender hierarchy.

\section{Eroticization of jūdō in Western mainstream and erotic media}

Eroticization and sexualization in both Western and Japanese mainstream media represent tendencies that are not exclusive to $j \bar{u} d \bar{o}$ and can be observed in many sports. Athletes have attractive, near perfect bodies that irradiate health and are thus ideal for commercials that market products with a relationship to health or adjectives usually linked to sports (fastest, highest, strongest, etc). However, the initiative to appear in media certainly has not been a one-sided demand from the media. Unlike tennis, golf, soccer, football, baseball and many other sports where athletes would attract million dollar contracts, such has never been the case. Top-jūiokka, certainly those of, or from before the 1980s have often complained of being unable to survive on what their performance brought in, in terms of finances. Thus, for jū $\overline{\bar{o}} \bar{k} a . .$. it was literally ANY chance or offer they received from the commercial industry or media to gain extra dollars they would jump on. In consequence, a number of jū $\bar{c} k a$, certainly those who were deemed as particularly attractive among their fellow-jū $\bar{o} k a$ used the media to their own advantages, and this was also extended to erotic media. Shortly before the Sydney 2000 Olympics Belgian $-56 \mathrm{~kg}$ national women's champion Inge Clement and her then boyfriend Atlanta 1996 heavy-weight bronze medal Harry Van Barneveld appeared naked in the inaugural issue (September 2000) of the Belgian men's magazine Menzo, as part of a series that featured several other Belgian Olympic hopefuls. The issue was a tremendous commercial success.

Somewhat later the "very Catholic" Belgian twofold world champion and seven-time European Champion (-61/-63 kg) Gella Vandecaveye appeared in a series of semi-nude pictures. In 2008, 20 -year old German European women's jū $\bar{o} \bar{o}$ vice-champion in the $-52 \mathrm{~kg}$ division Romy Tarangul (who one year later also would win bronze in the Rotterdam World Championships) posed nude in the September 2008 issue of the German edition of Playboy (Figure 6). 


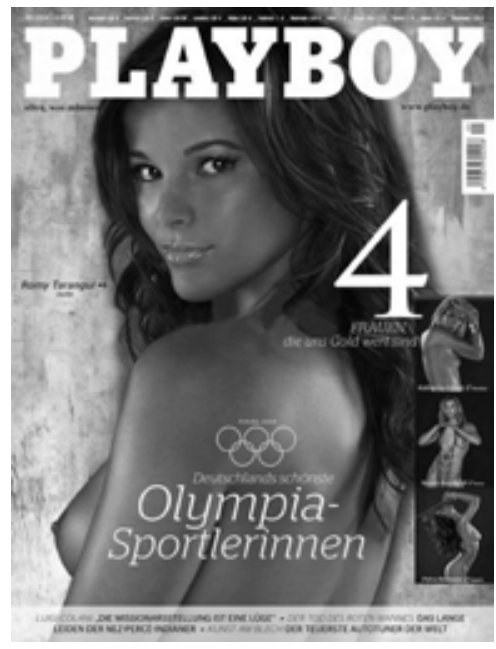

Figure 6: German European women's jūdō vice-champion in the -52 kg division Romy Tarangul (who one year later also would win bronze in the Rotterdam World Championships) here on the cover of the September 2008 issue of the German edition of Playboy for which she posed in the nude.

The Dutch even produced a special website (sportmeiden.nl) that featured nude pictures of a large number of Dutch top-athletes including the entire Dutch handball team, sprinter and jumper Frenke Bolt, body builder Erika Mes, discuss thrower Jacqueline Goormachtigh, track-and-field athlete Stella Jongmans, high-jumper Marjon Leeuwis, sprinter Henrieke Popken, gymnast Jeannette van Ravenstijn, 800m runner Majken van Reeken, Thai boxer Saskia van Rijswijk, and table tennis player Bettine Vriesekoop. The website was created with the purpose of creating income for the athletes. In order to visit the website, a fee of $€ 0.80$ was levied of which part went to the athletes. Despite the success, the website no longer is in existence, likely because oftentimes people who do pose nude at one point in their lives may regret the choice, in particular when after their competitive career is over they face concerns from more conservative potential employers or other business relations.

Nevertheless, since 2009, the Entertainment and Sports Programming Network (ESPN) in its ESPN The Magazine with its special "Body issue" has somewhat replaced the Dutch website, though it is catering for the in comparison to The Netherlands far more conservative American society, hence why all pictures of female athletes in ESPN avoid showing nipples or full frontal nudity. Especially their 2012 Body issue was noteworthy featuring $2007-72 \mathrm{~kg}$ vice-world $j \bar{u} d \bar{o}$ champion Ronda Rousey on its cover. Soon after its appearance the issue stirred the necessary controversy particularly in the light that Rousey was one of the most vocal critics in the 2009 Fletcher Thornton case about the USA Judo official who was accused of not having been able to keep his hands off female jū $\bar{c}$ athletes. Whilst, no doubt, 'seeing' does not imply 'touching', the question arises whether the female athlete in this way does not actively contribute to its own objectification. Does one put a glass of Scotch in front of someone keen on alcohol, or does one put a pack of cigarettes in front of a chain smoker, only to be surprised that the drinker or the heavy smoker will actually drink the Scotch and light the cigarette. Fair enough, those items are objects, not people, but that is precisely what is at issue here since sexuality in our society and in these athletes is used and this by both sides, each of them gets something out of it. The objectification thus does not occur merely 'accidentally'.

Perhaps, males suffer less retaliation being less judged on their physical appearance and being less objectified by society. Consequently, several male jū $\bar{o} k a$, such as notably Alert Holtman (The Netherlands, $-100 \mathrm{~kg}$ ), Renaud Carrière (France, -100 kg), Guillaume Chaine (France, -73 $\mathrm{kg}$ ), Frédéric Deltour (France) and Jonathan Schneider (France, $-81 \mathrm{~kg}$ ) have continued to pose naked for full frontal nude pictures which have been printed in magazines and circulate on the 
Internet on websites specialized in erotic or gay photography, irrespective of these men's own sexual orientation hence contributing to suggestions that can be easily misunderstood.

In 2005, French film director Antony Cordier launched his new movie Douches Froides [Cold Showers]. The movie is a tragic-comedy about three jü $\bar{c} k a$, one girl and two boys and the challenges they encounter in their adolescent life. The movie includes several typical jū $\bar{c} \bar{o}$ issues such as having to cut weight, randori, jūdō competition and the feelings one has when your friend does better/worse than you, etc. However, the movie is also provocative because of its sexual content, or at least, provocative to American audiences where full frontal nudity in mainstream movies accessible for minors is frowned upon. As the relationship between the three friends evolves the film reaches what has probably become its most famous scene, i.e. an after-hours ménage à trois between the girl and the two boys taking place on the tatami in the dojjo (Figure 7). The movie ended up winning several artistic awards, such as notably the Best Film at the French Golden Star, the Critic's Prize at the Marseille Film Festival, the Best Film at the Taipei Film Festival, the Grand Prize at the Verona Film Festival, and the Prix Louis Delluc.

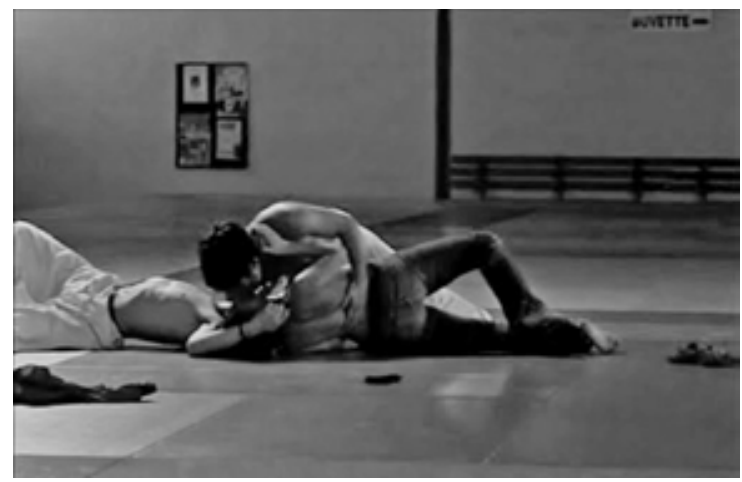

Figure 7: The infamous dōjō ménage-à-trois scene from the 2005 French jūdō movie Douches Froides [Cold Showers].

Several years ago a group of $j \bar{u} d \bar{o}$ and Brazilian "jiu-jitsu” (BJJ) enthusiasts started the website MatBattle (www.matbattle.com) which entirely and exclusively caters to the (male) gay jū $\bar{d}$ and BJJ community. The site includes articles, fiction, a forum, images, movies and a personals section. The issues is not so much that the site is run by people who are not heterosexual, but that the entire focus essentially is about eroticizing standard jūdo techniques, almost entirely newaza techniques as means for achieving sexual gratification during jū $\bar{o}$ practice. In this way, just like those approaching $j \bar{u} d \bar{o}$ as being nothing more than a sport, attempt to use and abuse jū $\bar{c} \bar{o}$ for something entirely different than it was intended by Kanō Jigorō. In doing so it is hardly a surprise that it leads to developments which jū $\bar{c}$ never envisaged having to deal with.

These examples show that the eroticization of $j \bar{u} d \bar{o}$ certainly is not an aberrant phenomenon solely in the mind of old perverted men just interested in using jjūdo to satisfy their needs. Instead, both young active jū $\bar{c} k a$, including several role models, as well as the media, either on their own initiative or on the initiative of the $j \bar{u} d \bar{o}$ world, shares the responsibility for the eroticization of $j \bar{u} d \bar{o}$.

\section{Eroticization of jūdō in Japanese erotic and pornographic media}

The existence and nurturing of inappropriate aberrant sexual behavior gets an even stronger impulse through the creation and availability of specialized erotic and pornographic audiovisual and literary media which depict and glorify jū $\bar{u} \bar{o}$ as a framework for all kinds of deviant sexual behavior. These media almost exclusively find their origin in Japan. These are mainly manga 漫画 cartoons. Manga can have a variety of topics, including action, adventure, comedy, historic, horror, romance, science fiction sports and games, historical drama, mystery, science fiction, and also sexuality. In the context of this paper it is those manga with a sexual character which are relevant. Manga were first developed around the turn of the $19^{\text {th }}$ century but really gained popularity 
around World War II. Manga were not generally spread or popular in the Western world. However, since the later 1990s these are now also widely available via the Internet, with especially those of a sexual nature having gained huge popularity.

Among these Japanese comics particularly the hentai seiyoku 変態性欲 [sexual perversion] topic, usually abbreviated to 'hentai', are of interest for the purpose of this paper. These include varies styles of specialization, such as notably: seijin 成人 [adult] or ero-manga エロ漫画 or ero-anime エロアニメ, redīsu komikku レディースコミック [ladies' comics], boizu rabu ボイ ズラブ [boys' love à aimed at women], gei komi ゲイコミ [gays' love], shōjo manga 少女漫 画 [teenage girls' love] and yuri 百合 [literally 'lily' which refers to 'lesbian'] or gāruzu rabu ガ ールズラブ [girls' love].

Each of these groups can have further subdivisions which more specifically characterizes the category to which they belong, such as: bakuny $\bar{u}$ 爆乳 [disproportionally large or bursting breasts], enjo kōsai 援助交際 [compensated dating, usually referring to secondary school girls being hired by much older men], futanari 二成 [hermaphrodite and transsexual characters], gosurori ゴスロ リ [Gothic Lolitas à involving girls dressing like puppets], incest [sex involving family members], meganekko 眼鏡っ娘 [girls who wear glasses], omorashi お漏らし [sex involving a full bladder, thus urophilia or 'water sports'], shōtarō konpurekkusu 正太郎コンプレックス [Shōtarō complex] usually abbreviated to shotakon ショタコン [Shōtarō comics à pedophilic attraction to young boys], zettai ryōiki 絶対領域 [absolute territory à referring to different grades of exposed thighs when referring to girls who are wearing short skirts and thigh-high stockings], Yamato nadeshiko 大和撫子 [humble and skilled in domestic tasks, i.e. the ideal for a Japanese woman as perceived by many Japanese men].

Prior to the late 1990s it was legal to sell and distribute real child pornography in Japan. It no longer is, but possession of child pornography still is legal in Japan. Restrictions on child pornography in Japan and in many countries do not extend to cartoons or virtual images of children if these do not involve real people, though they are illegal in Australia, Canada, New Zealand, Scandinavia, South Africa, and the US.

In sexual manga cartoons and hentai men, women and children are generally portrayed in a very specific way and according to stereotypes which exist in Japanese society about their sexuality. Gray (2008) describes the situation of sexuality and society in Japan as follows:

The availability of sex for sale makes female sexuality into a commodity; as MacKinnon puts it, 'women's sexuality is, usually, a thing to be stolen, sold, bought, bartered, or exchanged by others.' This changes the perception of rape, from a violent and humiliating attack on a person's autonomy, to theft of a possession. Furthermore, this concept robs women of sexual autonomy; they are mere objects, passive recipients of male desire. This is a gender-biased view: women's sexuality is constructed not from women's point of view, but from a (heterosexual) male point of view. This has far-reaching implications for the conceptualization of sexual assault.

There is a huge amount of pornography available in Japan, much of which depicts violence and degradation against females; rape-themed videos account for about $20 \%$ of the pornography at chain video-rental stores. Rape-centered pornography is also widely available in manga (cartoon) form. Pornography is considered so normal that men will often read violent manga pornography, or men's weekly magazines with high pornographic content, openly on the train, even when sitting next to female passengers.

In pornographic manga, sex, even when consensual, is generally something which is done to women rather than something in which they are active players. In fact, when female characters do express sexual desires of their own they are often rewarded with disinterest or anger from male characters. Furthermore, female characters are often shown as coming to enjoy their pain and degradation. The message this gives out to readers is that women should not express their own sexual autonomy, but should enjoy being the mere objects of aggressive male desire. Again, this is a gender-biased take on female sexuality, seen from the point of view of the male obtaining pleasure from the female rather than the female defining her own pleasure.” (...) [Gray, 2008]

The classical study often cited when referring to the potential link between pornography, rape and sex crimes in Japan, is the one by Diamond and Uchiyama (1999). These authors concluded that a massive increase in available pornography in Japan has been correlated with a dramatic 
decrease in sexual crimes and most so among youngsters as perpetrators or victims, probably because youngsters in generally have far less self-control when exposed to pornography, in particular pornography of a perverse nature. We note that the data used by Diamond and Uchiyama as a basis for their work were limited to a 23 year-window ranging from 1972 to 1995 , hence almost entirely predating the Internet area and thus the exposure of Westerners to Japanese hentai-like pornography

The various genres of hentai pornography discussed above lend themselves to visualizing, reading about and 'enjoying' every thinkable kind of sexual perversion. Of most of these types of perversions detailed above an offspring exists that may use $j \bar{u} d \bar{o}$ as a setting. These are obviously well appreciated by those who see $j \bar{u} d \bar{o}$ as a cover or target group for practicing pedophilia, child molesting, or forms of nonconsensual sex such as rape involving adults. Thus there exists a market for sexual $j \bar{u} d \bar{o}$ cartoons bridging most of the categories of perversions discussed above, including gay and heterosexual group rapes in the $d \overline{o j} \bar{o}$ with victims and perpetrators dressed in $j \bar{u} d \bar{o} g i$, voyeurism and masturbation, BDSM domination of weak men by a female black belt, usually without undershirt and in various stages of undressing, sodomizing pubescent jū $\bar{c}$ boys, etc (Figure 8).

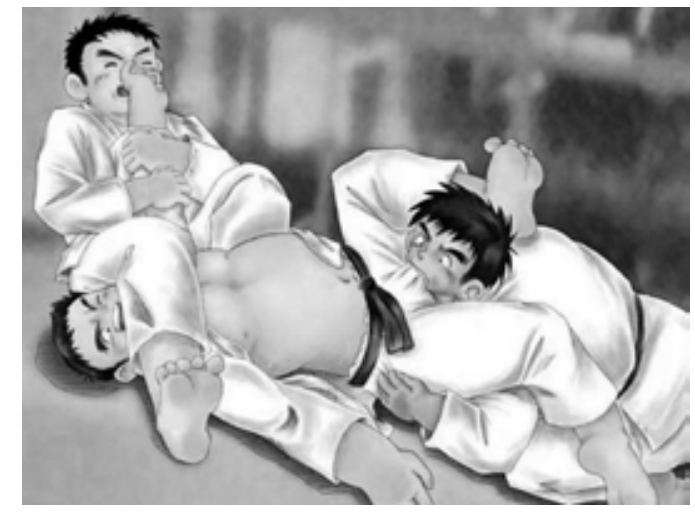

Figure 8: Typical erotic Japanese gay jūdō ero manga エロ漫画 cartoon of the gei komi ゲイコミ [gays' love] style, here depicting a threesome in which one male jüdōka is performing an ude-hishigi-jüji-gatame [arm overstretching with cross-control] to submit his opponent, while a third male jūdōka meanwhile performs sexual acts (usually fellatio, masturbation, or sodomy) on the submitted opponent.

One also notes that women involved in sex as depicted in hentai typically have child-like faces with excessively developed bodies and female shapes. In this way it transcends one of the clear separations that exist in real life, namely that the bodies of prepubescent girls and that of adult women look distinctively different in terms of sexual development. The fading of such clear distinction may contribute to those with weak self-control and a liking towards the very young for sexual purposes. The fact that these figures generally 'undergo' rather than actively participate for their own joy could create an amplification of the misperception that when such occurs in real life it is normal. While the market of jūdo cartoon pornography may not be very well known among the average Western jū $\bar{o} k a$, and the idea even shocking and disturbing, the existence of this material generally is far more familiar to those who seek out $j \bar{u} d \bar{o}$ or its network is being actively used as a vehicle for criminal intent.

In recent years $j \bar{u} d \bar{o}$ pornography has extended beyond cartoons and virtual reproductions. Mitsui Towa 蜜井とわ (likely not her real name as 'Mitsui' literally means “source of nectar" ...), born in Ôsaka, June $21^{\text {st }}$ of 1988, is a 23-year-old adult actress currently living in Fukui Prefecture 福井県. She stands just $151 \mathrm{~cm}$ tall while sporting an ample 41” (103 cm) J-cup chest entered the Japanese adult film industry in 2007. Besides these assets, Miss Mitsui also is the proud holder of a Kōdōkan nidan [2 ${ }^{\text {nd }}$ degree black belt] in jūdō. Between 2007-2009 she played in roughly 130 Japanese adult movies, several of them best described as jūdo pornography, such as, for example: Gen'eki jūdōka ga shōgeki no AV shutsu-en!! 現役柔道家が衝撃のAV出演!! [Active jūdō practitioner's shocking adult video performance!!] (Figure 9), Yume no saikyō chijō kyō-en! Jüdōka ga 
osaekomi bodībirudā ga nugasu 夢の最強痴女競演! 柔道家が押さえ込みボディービルダー

が抜 [Fantasy contest for the strongest female pervert! The jūdōka with a bodybuilder osae-komi control], Honmono jūdōka Mitsui Towa 本物柔道家 蜜井とわ [A genuine jū $\bar{c} \bar{k} a$ : Mitsui Towa], Osu！kyonyū jūdō-bu 押忍！ 巨乳柔道部 [Greetings！The Jūdō Giant-breasts Department], Jūdōka nakadashi nijū renpotsu 柔道家 中出し20連発 [Ajūdōka and a salvo of 20 ejaculations].

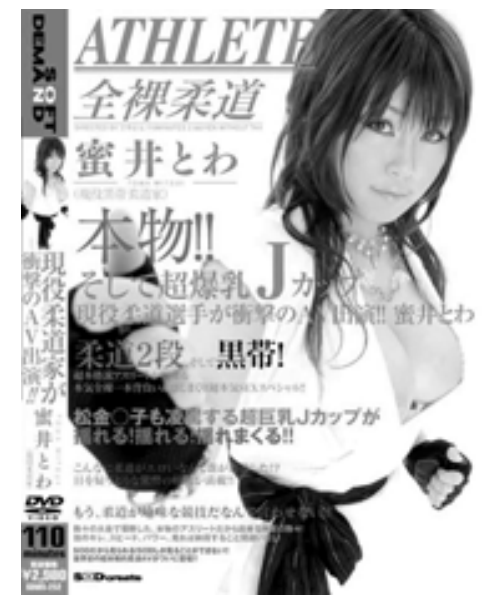

Figure 9: $\quad$ Cover of the adult Japanese jūdō X-rated movie Gen'eki jūdōka ga shōgeki no AV shutsu-en !! 現役柔道家が衝撃のAV出演!! [Active jüdō practitioner's shocking adult video performance !!] featuring the famous Kansai jūdō $2^{\text {nd }}$ dan black belt adult actress Mitsui Towa 蜜井とわ.

These movies are set in a jū $\bar{c} \bar{o} d \bar{o} j \bar{o}$ with the actors in various stages of undressed $j \bar{u} d \bar{o} g i$. In most of her jū $\bar{c} \bar{o}$ movies Miss Mitsui is objectified and passively undergoes a whole plethora of sex acts often bestowed on her by multiple men, sometimes entire groups, while she is humiliated, used and abused (Figure 10). Some of the movies depict BDSM fantasies with Miss Mitsui throwing around and choking out male jü $d \bar{o} k a$. But even when she is 'dominant' she is so because that is the desire of the male character who really is "topping from the bottom".

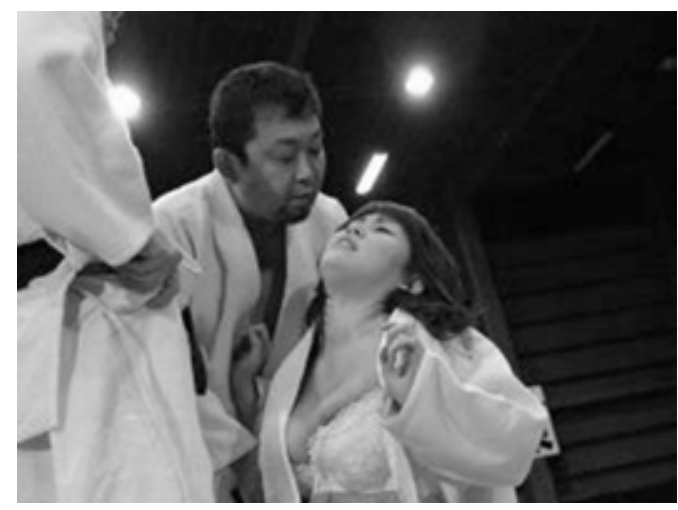

Figure 10: Kansai jūdō $2^{\text {nd }}$ dan black belt adult actress Mitsui Towa 蜜井とわ， depicted here in a typical Japanese eroticized jüdō scene where the female rather than 'actively enjoying' instead is forced to merely 'undergo' hence emphasizing the male-dominated socio-sexual relationship.

Nothing in the movies and cartoons is 'consensual'. Acts happen because one party, the one in charge, desires so. In this way it is that is what is the desire of the dominant character. In this way the reasoning of the child molesters, pedophiles, and other sex offenders in jū $d \bar{o}$ is very similar. 
They act following their desires with no concern for the other, their well-being, pleasure, future or the law. As there is no limit to the kinds of fantasies depicted in these cartoons and movies, they give a very strong visual representations to that what a jūdo sukebei otherwise could only create in his mind. The visual cues almost support self-approval, since the jūdō sukebei has now seen others practice what he has only dreamt about. Since others practice these acts, why should he not?

While in Western magazines such as Playboy a nude model's body is typically displayed in its entirety and accompanied by a narrative about the model's background and future aspirations in order to build in the reader a desire for a sexual-affectionate fantasy-relationship (Meloy, 2002), Japanese hentai and manga depict a whole other atmosphere, namely that of a "part-object relation". Thus the Japanese erotic media whether about $j \bar{u} d \bar{o}$ or other, frequently focus on part-objects only (a close-up of a breast, a buttock, a nipple, genitalia or sex act); there is no autobiographical description of the model left, and expressions of friendliness and affection have been replaced by negative sentiments, such as anxiety, fear and anger in this way also emphasizing the absence of consent. The interest of the reader is reduced to one of exploring, penetrating and violating the female object's personal boundaries, and detached from reality. Such part-object views are typical for paraphilias and sexually aberrant behaviors (Meloy, 2002). Particularly if a jū $\overline{\bar{u}}$ athlete, instructor or coach shows behavioral traits that may predict or reflect underlying psychopathic tendencies, exposure to such media may potentiate them engaging in initiating sexually aberrant behaviors with $j \bar{u} d \bar{o}$ athletes. Psychopathy is characterized by aggressive narcissism and chronic antisocial behavior, and by an arrogant and deceitful interpersonal style and deficient affective experiences, which further delineating the core personality of the psychopath (Meloy, 2002). Psychopathy certainly has emerged as a significant and powerful predictor of repeat sexual deviant offences (Meloy, 2002).

As much as jū $\bar{o} \bar{o}$ in Kanō's view should not be about power, in reality it very much is: physical power and domination of the other in terms of winning in randori and in jū $\bar{o}$ contests, psychological power and domination in terms of personal interactions and gratifying one's desires. Instead of $j \bar{u} d \bar{o}$ as a means to realize its principles, $j \bar{u} d \bar{o}$ has come to be used as a vehicle to achieve one's own goals no matter much those goals or the process to achieve them may be in contraction to the goals of $j \bar{u} d \bar{o}$ as defined by Kanō Jigorō.

\section{Jūdō for all and the metaphysical solidity of Kōdōkan jūdō’s moral foundation}

Kōdōkan jū $\overline{\text { o }}$ 's second principle, the Confucianism-inspired Ji-ta kyō-ei 自他共栄, as indicated before, means "Mutual prosperity and harmony for everyone". In Kanō's view, the whole of society should be the primary beneficiary of $j \bar{u} d \bar{o}$, something that is achieved through each individual striving for the utmost morality.

The 'ei' 栄 in ji-ta kyo-ei implies a state of accomplishment of the self, i.e. the maximal physical and mental/spiritual development of the individual within his social environment. This principle builds on the understanding that man is born without evil. Thus it only requires cultivation of his inborn good character to develop into a responsible and kindred citizen. Self-discipline and education fulfill a central role in accomplishing this process. This self-discipline and education should lead to a person developing the ability to make proper judgment between good and bad (Kanō, 1911). In Kanō's view, when surrounded in jū $d \bar{o}$ by others, particularly by those more senior than you, this would imply being surrounded by people of high moral level whose influence logically should bring the student to a higher moral level.

The concept of $e i$ as used by Kanō likely builds on both Taoism and Confucianism, with the Confucian virtue of jin 仁, meaning 'benevolence' or 'humanity', offering fundamental support for the development of ei in Kanō's view. Jin is part of Jingireichishin 仁義礼智信, i.e., the five Confucian virtues, of which jin is considered the highest and most important (Kanō, 1911).

In May 1889 Kanō held a lecture before the Dai Nippon Kyoikukai 大日本教育会. This lecture represents the oldest preserved document in which Kanō elaborates about the foundations and conceptual framework of Kōdokan jūdō. Kanō followed this up in 1917 with an article in the Kōdōkan's magazine Jūdo entitled Onore no tame ka yo no tame ka 己の為ためか世のためか 
[To one's own usefulness and that of the world] (Kanō, 1917), and by another article in 1926 under the title: Sei-ryoku zen'yō ji-ta kyō-ei ni kan suru shitsumon ni kotau 精力善用己自他共栄 に 関する質問にこたう[Questions and answers regarding the efficient use of energy and mutual prosperity] (Kanō, 1926). In these writings Kanō inter alia argued:

"In moral education just as in the case of intellectual training, in order to employ sei-ryoku zen'yo 精力善用 [Best use of energy; note: this is jūdō's other main principle], it is essential that we clearly define the goals we wish to reach." (Kanō, 2006, p. 68-70)

"When people are by themselves, the principles of sei-ryoku zen'yō can be applied without any trouble, but when there is a group of two or more people, it simply takes one person to act selfishly, and conflict can easily arise. But if every party in a group avoids acting selfishly and acts considerately to the needs and circumstances of the other people in the group, then conflict can naturally be avoided and harmony achieved. Conflict is to a mutual detriment just as harmony is to a mutual gain.

Thus, if a group of people lives together, not only can those people avoid offending each other, they can also help each other. There are things that cannot be done alone, but need the assistance of others. Furthermore, the virtues and strengths of one can complement and foster those of another. Accordingly, the situation affords advantages to each of them that they would not have alone. This is called sōjo sōjōji-ta kyō-ei 相助相譲自他共栄, which means 'mutual prosperity through mutual assistance and concession'. This may be shortened to ji-ta kyō-ei 自他共栄 [mutual prosperity].

For this reason, if each member of a group helps others and acts selflessly, the group can be harmonious and act as one. Accordingly, the group can make the best use of its energy, just like an individual. This principle remains true even in the case of a complex society with a population of millions. So, if sei-ryoku zen'yō [efficient use of energy] and ji-ta kyō-ei are realized, social life will naturally continue to progress and develop, and as members of society, everyone can achieve the results they hope for." (...) (Kanō, 2006, p. 70-71)

"With regard to our daily activities and social interaction, the teaching of sei-ryoku zen'yo means bringing about maximum results through the use of every sort of energy. For this reason, human faults like anger, for example, violate this principle. Becoming angry consumes mental energy. How does anger benefit you or anyone else? The results of anger are invariably a depletion of mental energy and being looked down on or disliked by others. By following the principle of sei-ryoku zen'yō, people will not get angry.

Being disappointed or troubled by failures or setbacks, or harboring grievances are also ways in which mental energy is consumed. Arguments, fights - all these things are violations of sei-ryoku zen'yō. Those who practice jūdō must take great care to follow this teaching. No matter what the situation, there is only one path that people must follow -in every case, the only course is to consider what is the right thing to do and proceed in that direction." (...) (Kanō, 2006, p. 84-85).

Even though Kanō speaks about a certain dichotomy between acting in one's own interest $v s$. acting with the best interest of the world in mind, there are other texts where he seems to suggest that this separation is merely artificial, since in practice oftentimes when society improves this is also in the interest of the individual, and when an individual benefits, society as a whole oftentimes benefits. However, this process is not independent of that what drives the individual and what his desires may be.

People generally have goals. Now and then they act subconsciously, but typically there is a motive behind their actions. This leads to the question: do they act in their own best interests or in the best interest of the world? If one acts in one's own interest then one may at first act in this way because one can. Then comes the desire to develop oneself, and thirdly one may act to realize one's desires. When people act in the best interest of the world they have the following goals: first, in the best interest of those surrounding them, such as parents, siblings, family, and friends, secondly in the interest of old school mates, patriotic organizations, student organizations or the company one works for, and third, for the society, the country or humankind (jinrui 人類).

To ensure the wellbeing of this process, according to Kanō, a high level of moral and ethics should guide people in their decisions and desires. In doing so, Kanō contrasts what he calls mikaijin 未開人 [“an uncivilized person”] vs. bunmeijin 文明人 [“a civilized person”]. Kanō sees the difference between both in their goals being of a material $v s$. intellectual nature. A civilized 
person understands the natural functioning of the world that surrounds him and is able to use his scientific knowledge and wisdom to carefully bring under control some of these processes to improve the fate of man. Thus, individual fortune and benefit of the entire nation, according to Kanō, should be tightly connected.

Kanō's view is essentially utilitarian, but as such is subject to the same criticisms uttered by the famous German philosopher Immanuel Kant. In many of our decisions we will face a choice between what is right (the best for society) vs. what is good (the best for us). Kant solves this problem by considering the 'right' superior to the 'good'. For Kant, the 'good' was morally irrelevant. In his view, a person cannot decide whether conduct is 'right' or moral, through empirical means. Such judgments must be reached a priori, using pure practical reason. "Pure practical reason" for Kant is different from both pure reason (the capacity to know) and practical reason (which allows us to interact with the world in experience). Reason, separate from all empirical experience, can determine the principle according to which all ends can be determined as moral. It is this fundamental principle of moral reason that Kant calls his Kategorische Imperativ [categorical imperative]. Thus for Kant, such decisions will be objectivist rather than subjectivist. Such moral universalism implies that really those acting accordingly should come to the same decision when presented with a choice.

Kant argued that any action taken against another person, to which this person could not possibly consent, is a violation of perfect duty. If a thief were to steal a book from an unknowing victim, it may have been that the victim would have agreed, had the thief simply asked. However, no person can consent to theft, because the presence of consent would mean that the transfer was not a theft. Similarly, lying or deception of any kind should be rejected under any interpretation and in any circumstance. Suppose one would seek to borrow money without intending to pay it back. This would be a contradiction because if it were a universal action, no person would lend money anymore as he knows that he will never be paid back. The maxim of this action results in a contradiction in conceivability. Lying, for example, would logically contradict the reliability of language. If it is universally acceptable to lie, then no one would believe anyone and all truths would be assumed to be lies. The right to deceive could also not be claimed because it would deny the status of the person deceived as an end in itself. Therefore one does not have the right to lie or deceive for any reason, regardless of context or anticipated consequences.

Kanō's ji-ta kyō-ei is merely a principle rather than a comprehensive philosophy in itself and thus appears far less elaborated than Kant's philosophical views. Kanō does not seem even to accept the possibility that someone might simply act in a different way than he would like or would recommend. Kanō also does not seem to discriminate for differences in cultural perceptions of that what might be best for humanity. Even those supposedly guided by objective assessment, such as, for example, scientists, may not always agree about what is best for society. The utopian nature of Kanō's views was already shown in many aspects during Kanō's own life, and he failed to offer a suitable response. Kanō's view is one of "one should" with little alternative if "one does not what he feels one should". In fact, the construct of $j \bar{u} d \bar{o}$ itself is, or at least, has become, largely utopian as it has very little means in place to properly train and educate the student towards achieving these (utopian) goals. For example, it is very unclear how even in pure jū $\bar{u} \bar{o}$ matters such as obtaining medals or dan-rank promotion the benefit of society guides these principles, or, in reverse sense, how any of these goals successfully achieved by an individual lead to the benefit of society? They may or may not contribute to each other, and nothing suggests that the outcome relies on anything more than the mere personality of the individual. Kanō's philosophy barely offers an answer for unethical or criminal behavior. Kanō merely suggests that it is not good if it exists, and he hopes, maybe in a delusional way, that it should not exist or will disappear through the practice of $j \bar{u} d \bar{o}$.

Kanō also seems to argue that the intellectual formation that in his view should come with $j \bar{u} d \bar{o}$ should install a desire in the student to better his mind and body. People take up $j \bar{u} d \bar{o}$ for all kinds of reasons: martial arts training, health, because they want to learn how to fight. The reality though is that it is nearly unseen for anyone to take up jū $\bar{u} \bar{o}$ with a commitment to increase his intellectual level through it. Among those who seem to evolve the most in jū $\bar{o}$ success is typically measured in terms of medals and championships won, in terms of dan rank promotion, or in terms of champions produced as an instructor or coach, but not at all in terms of intellectual achievement. 
In fact, the jū $\bar{o}$ establishment looks with great suspicion to intellectual achievement since such

achievement is only achievable through merit and literary and mental practice or challenge rather than through politics, fighting or pumping weights. As such, intellectual achievement in jū $\bar{u} \bar{o}$ or through $j \bar{u} d \bar{o}$ is diametrically opposed to how Kōdokan jū $\bar{o}$ has deviated after Kanō's death and how it has led to the current jū $\bar{u} \bar{o}$ establishment.

Why does virtually no one take up jū $\bar{c}$ for intellectual reasons? Because, $j \bar{u} d \bar{o}$ has never been marketed in the West as being much else than a sport and a set of combat tricks and novices generally do not know jū $\bar{o}$ even has an intellectual dimension lest they would use it as a reason

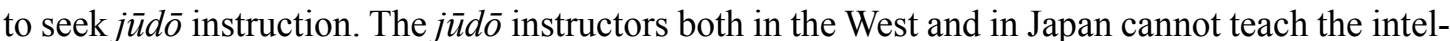
lectual dimension of $j \bar{u} d \bar{o}$ having never learnt it themselves, because the jū $\bar{o}$ didactic material especially that which exists in non-Japanese languages contains only information about combat technical skills and how to improve contest performance, with the majority of significant material about the intellectual component of $j \bar{u} d \bar{o}$ existing only in old prewar Japanese books long out of print. Appreciating the intellectually gifted or intellectual achievements in or through $j \bar{u} d \bar{o}$ would create a dramatic shift in current jū $\bar{o}$ power structures. In the absence of any such intellectual dimension it is only natural and logical that $j \bar{u} d \bar{o}$ and those practicing it cannot but fail to achieve the ethical goals which Kanō projected. In the absence of such development, any vice present and observed in society is to be suspected present in jū $\bar{u}$, some of them even potentiated through $j \bar{u} d \bar{o}$ because the jū $\bar{o}$ climate is conducive to their cultivation and growth. Yet, when Kanō was still alive, it was precisely this intellectual and moral development which he emphasized through $j \bar{u} d \bar{o}$, as is clear from his writings and from the last survivors who still had received tuition from him in person, such as, for example, Fukuda Keiko (1913-2013). For Kanō, even the link between practical jū $\bar{o}$ training and technique as a stairway to enhanced morals was a truism:

"Since the establishment of the Kōdōkan I have continued to explain to those who practice it that Kōdōkan jūdō is originally a teaching of the literary and military arts, and one must begin with waza [techniques] when embarking on the dō [the Way] of jūdō. But many people, although they make rapid progress with waza, require a great deal of training in order to reach the point at which they can appreciate the dō. Though many people have an interest in exercise and make an enthusiastic study of its secrets, unfortunately there are those who remain quite indifferent to mental training. In the practice of jūdō, if energy is not applied to mental training in particular, that aspect is likely to be neglected. So you must proceed, taking care with your training, and embark on the dō with a sincere commitment to waza and mental development." (...) (Kanō, 2006, p. 65)

"People may say that the balance between intellectual training and moral education is not something that can be quantified, and therefore determining things like this balance, in advance is futile.

This is, of course, perfectly reasonable, but the balance does not necessarily need to be quantified. That is to say, the relative weight of each can be compared by suggesting that perhaps intellectual training should be emphasized more than it is today or that moral education should also be emphasized. Accordingly, if we can achieve at least that, it will become easier to set goals, and once these are set, the means of achieving them will naturally be implemented." (...) (ibid.)

"I began this discussion by suggesting that we must remember that intellectual training involves both the acquisition of knowledge and the cultivation of mental power, and whereas one cannot discuss these as entirely separate things, it is nevertheless true that people with a great deal of knowledge do not necessarily have exceptional powers of reasoning or judgment. The cultivation of these powers does not in itself entail becoming knowledgeable, so in fact, these two things can be looked at separately. Thus, in education the question of whether to place greater emphasis on the cultivation of mental power or to put greater effort into the acquisition of knowledge may arise." (...) (Kanō, 2006, p. 67)

Even though Kanō opines that people are born 'good' rather than evil, they must learn through intellectual education that what is 'good'. But the word 'good' here -in translation - rather seems to coincide with Kant's 'that what is right' and thus ... that which must be set a priori, as opposed to that what is 'good' in Kantian sense, that is that which can be empirically achieved:

"In one respect, moral education must be carried out from the aspect of knowledge. That is to say, it is necessary to know intellectually what is good and what is evil. It is also necessary to 
develop the intelligence to distinguish right from wrong in various complex situations. Thus it is necessary to teach the ability to determine good from bad; to discriminate what is right from what is wrong." (...) (Kanō, 2006, p. 68)

Kanō does not single out 'intellectual' training as the sole valuable premise on which a moral dimension can be built. In fact, next to the intellectual component, the emotional component is equally important in a sense that Kanō desires that the accomplished jūdōka would be of moral virtue simply because that is what he 'likes' and finds attractive, and would reject the immoral simply because of 'dislike':

"In another sense, moral education must be carried out from the aspect of the emotions. Even if you can distinguish right from wrong intellectually, if you are not trained emotionally to like what is good and dislike what is evil, your ability to do good and reject evil will be lacking. So if morals are not cultivated both intellectually and emotionally, good results cannot be achieved.

Furthermore, even if your try to do good and reject evil, if your willpower is weak, the opposite result will often occur. Therefore, training of the will must also be an element of moral education - a weak willpower can result in the inability to do what you know is right, or the inability to prevent doing what you know is wrong.

It is also important not to overlook the element of habit. Even if you intend to do good, if you have not developed the habit of doing so, your best intentions will easily be corrupted. And even the best intentions of rejecting evil can fail if you have not developed the habit of doing so. For that reason, you must endeavor to cultivate good habits, love what is good, and reject what is evil on a daily basis." (...) (Kanō, 2006, p. 68)

In his May 1889 lecture before the Dai Nippon Kyōikukai 大日本教育会（= the oldest preserved document Kanō talks about jukuryo dankō 熟慮断行 [thoughtful yet decisive action] and about tomaru tokoru o shire 止まる所を知れ [know when to stop], or: “do not cross the (moral) line". Kanō really was talking about how to conduct oneself during practical jūdō, but given that he saw practical jū $\bar{o}$ as the way towards morality in general, the same principles in his view would have to apply outside of the jūdo tatami [mat] and outside of the dōjo [training hall for practice of the Way].

Those who are in jū $\bar{c} \bar{o}$ and commit sexual offences, and those who seek out jū $d \bar{o}$ as an environment to indulge in sexual offences with children or nonconsenting adults, did not act in a 'thoughtful' way; they did not know when to stop, and did they cross the (moral) line. They either did not fully realize the difference between good and evil, or they were mentally too weak to intellectually reject evil or to emotionally dislike evil. However, some perpetrators did act with the consent of the other, such as those who were merely in violation of laws of statutory rape without necessarily being in violation of ji-ta kyo-ei or the best of society. After all, each law is not necessarily written in the best interest of society and neither may a strict application of the law be in the best interest of society. For example it could very well be that two jū $\bar{c} \bar{k} a$ have a loving relationship, intend to get married and have consensual sex one week before the person reaches the minimal age allowed by law for sexual relations. Even if a law in general may serve society best, it does seem that a rule utilitarian interpretation and application would have been able to serve both society and this couple in an optimal way.

\section{Disintegration and absence of Kanō Jigorō's core moral philosophy in contemporary jüdō practice and jüdō's coach and instructor training}

Another reason why jū $\bar{d} \bar{o}$ has attracted jū $\bar{u} \bar{o}$ sukebei and has been a safe haven for them is that $j \bar{u} d \bar{o}$ instructors today are no longer trained and have not been trained in the moral aspects of $j \bar{u} d \bar{o}$. This is true both in the West and in Japan. Morality and ethics, once the praised goal of the accomplished jū $\bar{o}$ student have become almost alien concepts to contemporary jū $\bar{o}$. Until the 1970s it was common for jū $\bar{o}$ instructors to possess no formal instructors' or coaches' training and credentials. Jū $d \bar{o}$ instructorships were simply assumed by those who founded the jū $\bar{u} \bar{o}$ club. By the early 1980s many jū $\bar{o}$ federations had at least some elementary instructor's and coaching course in place. In some countries, such as for example, Belgium, where the courses were administered under the authority of the Ministry of Health \& Sports, these were rather extensive 
courses bridging between 10 to 16 weekends of attending classes followed by formal exams and a concluding written piece of work; in other countries, such as, for example the US, basic coaching qualifications required nothing more than sitting half a day or a day in a room listening to someone talking, while no exams or other evaluation of the attendees' skills or knowledge were included. Despite organizational and structural differences all these courses had in common that they focused on jū $\bar{o}$ technique, optimizing a jūdo athlete's contest skills, gaining knowledge of supporting topics to achieve these goals (anatomy, physiology), but all ignored introducing and properly educating future instructors and coaches into what Kanō's jū dō was really about, i.e. the educational dimension and moral goals. Why these are not incorporated is simply because the curricular and steering committees and the teaching staff generally possess this knowledge, and because there is virtually no demand for it.

Yet, it has not always been like this. The first formal jū $\overline{\bar{o}}$ instructors' course was established in April of 1911 following an ever increasing demand for Kōdōkan instructors. It was called Kōdōkan Jūdō Kyō'in Yōsei-jo 講道館柔道教員養成所 [Kōdōkan Jūdō Teachers' Training Place] (Bennett, 2009, p. 137). This course lasted a full three years ! In comparison, USA Judo's current E-level Coaching course takes up less than one full day without any exam. The emphasis of the Kōdokkan jū $\bar{o}$ teachers' training was not just on technical skills, but equally on intellectual knowledge and moral character. For example, there was a vast component on ethics, which was taught by Endō Ryūkichi 遠藤隆吉 (1874-1946), an important educator who at that time (since 1900) was a lecturer at the Tōkyō Kōtō Shihan Gakkō 東京高等師範学校 [Tōkyō Higher Normal School]. On top of that, the course had a prerequisite that one already needed to hold a degree from a teacher's college in order to be eligible for admission. Oda Jōin 小田常胤 (1892-1955), known for his deep understanding of $j \bar{u} d \bar{o}$, was amongst the first graduates (1914). The financial burden to continue the school and the low number of student applications caused it to close its doors relatively shortly after the first class graduated. Hence the major formal tool for initiating students into the educational dimensions of $j \bar{u} d \bar{o}$ was gone.

There were still the articles which Kanō authored in the various Kōdokkan journals, such as Kokushi 国士 [The Patriot], Yūkō-no-katsudō 有効の活動 [The effectiveness of movement], $J \bar{u} d \bar{o}$ 柔道, and $S a k k \bar{o}$ 作興 [Promotion], and there were the lectures (kōgi 講義) he gave at the Kōdōkan, and there were the questions \& answer discussions (mondō 問答), but there was no mandatory attendance to the lectures or reading or studying the texts of the articles.

In any case, the absence of extensive and continued training in ethics and moral development in the formation of jūdō instructors' since the demise of the Jüdō Kyōjin Yōsei-jo and the Busen are responsible for these important foundations of $j \bar{u} d \bar{o}$ no longer being transferred to new jū $\bar{c} \bar{o}$ students. Hence there is little left in jū $\bar{c} \bar{o}$ that functions as a form of therapy for those with deviant, inappropriate or immoral behaviors. On the contrary, the emphasis on fighting and winning combat and the sportification of $j \bar{u} d \bar{o}$ and ensuing stressors already in children increase several parameters of concern such as aggression and antisocial behaviors.

\section{Challenges to the jüdō community and federations confronted with sexual misbehavior}

There is no question about it that whatever happens or is common in jū $\bar{o}$ has no discernable effect on the law and how the law is interpreted by a judge. On the other hand, as we already have shown, jū $\bar{o}$ through its moral dimension should have an effect on the perpetrator. However, there are more key players in this equation than the law as enforced by police, court and judge and there is also the perpetrator and the victim(s). There are, however, additional key players, namely the $j \bar{u} d \bar{o}$ community in terms of the perpetrator's social environment, the jū $\bar{c} \bar{o}$ federation which governs his administrative rights, and the club or organizer during whose event the offensive act might have taken place.

How does the $j \bar{u} d \bar{o}$ community as a social environment, or the federation and organizer deal with such perpetrators? Privacy reasons in most European and Asian countries make it hard to analyze $j \bar{u} \bar{o} \bar{o}$ disciplinary measures that have been taken for sexual offences, but it seems the issue often is left to law enforcement to deal with it (Brackenridge, 1999; Brackenridge et al., 2008; 
Fasting et al., 2011). If a victim does not press charges or law enforcement decides to not pursue a case then this is accepted and it is the end of it. However, jūdo organizations in the US seem to take a view diametrically opposed to this view and in recent years have always expelled the person irrespective of the degree of seriousness of the alleged sexual offence, likely out of fear of litigation. Views from Americans on public forums tend to support a view that such an offender ideally should be banned for everything for life with no punishment being harsh enough irrespective of the nature of the sexual offence including many situations where the 'offence' is merely a 'technical' matter.

Even though US organizations eagerly refer to due process being applied, an expression readily adopted by those commenting, the reality often is quite different, with numerous legal flaws and violations of the rights of the defense, the case often decided before an actual hearing, if one takes place, penalties being reciprocated thus the punishment being expanded by other organizations without a hearing, etc. (Siekman \& Soek, 2001). The above legal concerns are endemic to the disciplinary proceedings in sports organizations both in $j \bar{u} d \bar{o}$ and other sports. Sports organizations often like to simultaneously play judge and jury, but in reality usually simply neither have the expertise to do so properly, independently, and objectively, as pointed out by several legal scholars (Siekman \& Soek, 2001). Executive powers and judicial powers within sports organizations are often not sufficiently separated, and sometimes not at all (Siekman \& Soek, 2001). The desire for specific punishments are often internally made clear by executive powers within a federation even before the actually disciplinary proceeding has started and the accused has been heard. Disciplinary rules are unacceptably vague, with oftentimes the type of penalty per type of offense not being anywhere in such rules, thus leading to an unacceptably width of adjudication (Siekman \& Soek, 2001). Small offences could get life expulsion while serious offences could get just a warning, if the executive powers push their disciplinary committee to do so. Disciplinary committees are eager to submit to the wishes of the executive power for the same reason so many things in $j \bar{u} d \bar{o}$ are the way they are: the influence of executive powers on future dan-rank promotion and other perks of members of disciplinary committees. Disciplinary records of $j \bar{u} d \bar{o}$ federations are so atrociously poor that, really, the only sound thing to do is to refer $j \bar{u} d \bar{o}$ disciplinary proceedings to a committee of professional legal experts not associated at all with that federation, and making their decisions binding for the federation without any need for confirmation or involvement of the $j \bar{u} d \bar{o}$ federation's executive branch. This would be the best way to serve the interests of the victim, of the perpetrator, of the federation and certainly of $j \bar{u} d \bar{o}$ itself. Meanwhile there are also positive developments to report such as particularly the many information campaigns and preventive actions that are or have been launched by national governments in order to sensitize young players, their peers, parents, officials and instructor staff to signs of inappropriate behaviors (Brackenridge, 2004; Brackenridge et al., no date (a), no date (b); NSVRC, 2005; Vlaamse Overheid, 2012; Vlaamse Regering, 2012).

Considering these measures when plotted against the background of Kōdōkan jūdō's philosophy, one discerns some strange disparities. If $j \bar{u} d \bar{o}$, as shown previously in this paper, primarily aims to develop one's moral dimension, by strengthening one's character, by helping one dislike evil and like good, by sensitizing one for developing both one's intellectual and emotional basis to support a high moral conscience, then why are those apparently in need the most rejected from $j \bar{u} d \bar{o}$. Presumably, and likely for obvious reasons, concerned parents of children would act with outrage and disgust if a jū $\bar{u} \bar{o}$ club or federation were to employ a known sex offender in an instructor's position to work again with a group of people similar to those where he or she had already caused victims. However, this is not what we propose. If the jū $d \bar{o}$ community, in particular those most senior within that community, take up their role and responsibility within jū $\bar{u}$ 's moral dimension, then they should commit to invest in those who need their help most. A jū $\bar{c} \bar{o}$ instructor known to have behaved inappropriately in the vicinity of children could, for example, be denied the privilege to work with children, whereas engage himself more with senior adult jū $d \bar{o} \mathrm{ka}$; a jū $\bar{o}$ coach known to have behaved inappropriately with female jū $\bar{o}$ ka could be denied the privilege to work with and be alone with women while focusing on jū $\bar{o}$ training exclusively with men. In this way the offender's $j \bar{u} d \bar{o}$ learning and perhaps more importantly, $j \bar{u} d \bar{o}$ 's "correctional process" may achieve something far closer to Kanō intentions than simple expulsion. Whilst there will be those $j \bar{u} d \bar{o}$ officials or community members who will argue that by expelling the offender they 
have taken up their responsibility, maybe what they did is sidestep that responsibility and leave it up to others elsewhere. It does not take a lot of responsibility and personal investment to say 'no', but it takes a huge amount of time and responsibility to assist someone in bringing him or her to a higher moral level.

\section{Malicious and false complaints of sexual harassment}

There exists a heightened sensitivity towards pedophilia and sexual harassment of children and adolescents in society. People easily will feel outraged at such offences not just out of sympathy with the victim, but because they often relate to their own children potentially being a victim of a sexual predator. Because of this heightened sensitivity and because when such crimes are committed, oftentimes only the perpetrator and the victim are present without further tangible evidence, the actions taken by a disciplinary committee or law enforcement may often depend on the extent to which the person can convince someone of the veracity of the version of her/his story. People with less honorable motives know this too, and most unfortunately, claims of sexual harassment, molestation and rape can also be false. According to Hayez et al., (1994), when a child under age states he/she has been sexually abused, there seldom exists an objective certainty to support the allegation. Whereas clinicians know that a child who speaks spontaneously probably speaks the truth, it is nonetheless difficult to exclude the possibility of fabricating, lying or mistaking. These authors also concluded that the error probability is sharply increased when abuse is referred by a parent, especially in a context of parental separation ...

The extent of false sexual harassment complaints in jū $\bar{u} \bar{o}$ is unknown. However, it is also a common belief by many senior jū $\bar{o} k a$ that jū $\bar{c} \bar{o}$ is its own worst enemy (Kanō, 2007) ... In the recent Joop ter Heegde case in Rotterdam, several newspapers reported that at least part of the allegations might have been fabricated (Verspeek, 2011). If such were to be true, the damage to the accused might be of astronomical proportions. Apart from his business reputation and social position having heavily suffered, it is likely that Internet searches for many years to come, due to information being cached, will keep yielding returns suggesting that one is a sex offender irrespective of whether the person will be exonerated or not. In this way, a person's chances for employment and new business or personal relationships may be permanently severely curtailed. If so, then it is only reasonable that restitution of his damage to the highest extent is made by those engaging in false accusations. The federation or association that was drawn into the matter by such a false complaint should severely penalize a bogus accuser to discourage such abuses of the disciplinary or judicial system.

Furthermore, the role of the media also may be questionable. For example, in 2004 Richard van Deun was convicted to 12 months in prison and 6 months of probation for pedophilia with 5 boys from his $j \bar{u} d \bar{o}$ club during the 1992-2002 period. The acts did not involve any penetration and were limited to inappropriate touching, and court proceedings showed that the perpetrator had an insufficiently realistic insight and judgment. The person left $j \bar{u} d \bar{o}$, completed his sentence, and sought psychiatric treatment. There was no indication he was a recidivist. Nevertheless, in June 2012 a Dutch newspaper 'exposed' the man because he was teaching chess, including to children, in a chess club (Endedijk \& van Steenbergen, 2012). Further investigation showed that van Deun did not commit any inappropriate acts since his conviction or with anyone in the chess club. Neither was he violating the terms of his sentence, which he had correctly finished. Nevertheless, even though van Deun made no new offences he was forced to cease his involvement at the chess club. Thus, the motives of a newspaper that finds it necessary to 'expose' a person who has successfully and appropriately integrated himself back into society are questionable. The question then rises why even have a justice system if people who complete their sentence and reintegrate themselves in society is apparently not enough for the newspaper, which seems to suggest that a person who made a mistake and completed his sentence should continue to be sentenced again and again, and continuous additional sentences be imposed on him even though the Court which convicted him at the time decided otherwise. Together with fabricated sexual harassment complaints this is just another worrisome concern to add to the pain and damage caused by any offence of a sexual nature. Morality and ethics, once the praised goal of the accomplished jū $\bar{o}$ student have become 


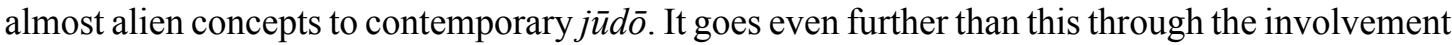
of criminal activity where $j \bar{u} d \bar{o}$ or its network is being actively used as a vehicle for discriminatory and criminal intent. There are other serious cases of abuse in $j \bar{u} d \bar{o}$, i.e. those of a nonsexual nature, but these are beyond the scope of this present analysis.

\section{Conclusions}

$J \bar{u} d \bar{o}$ was intended "for all". In reality, a number of disturbing incidents continue to show that certain populations have heavily suffered through $j \bar{u} d \bar{o}$, essentially showing that $j \bar{u} d \bar{o}$ has a long way to go before approaching Kanō's "prosperity for all" objective. Cultural conceptions and jurisprudence are factors that affect how people perceive the seriousness of different sex offences. The legal system should primarily deal with sex offences, as it does a far better job in being objective and respecting the rights of both the victim and defense than the jū $\bar{c} \bar{o}$ organizations. Jü $\bar{o}$ organizations instead should start focusing on their educational role besides just winning medals. They should take up their responsibility in both sufficiently protecting the weak from sex offenders, and in integrating past offenders to educate them through $j \bar{u} d \bar{o}$ activities that do not involve their victim target groups. Simply expelling an offender rather is way to not take up responsibility in terms of $j \bar{u} d \bar{o}$ 's moral engagement, when compared to showing commitment to actually teaching and improving a person in need of moral guidance. After learning why jū $\bar{o} \bar{o}$ attracts sex offenders the $j \bar{u} d \bar{o}$ federations should in a constructive way work towards diminishing opportunities that attract sex offenders. For example, there is no need for strangers or multiple people to be present during naked weigh-ins. Privacy can be easily achieved with very little effort. Juveniles should be accompanied by chaperones. Sex offences should be anticipated and openly discussed in a constructive way in terms of how to recognize early signs and how to bring them to attention, and provide stricter moral control and mentorship. Federations and senior instructors should increase the awareness of junior coaching staff of 'grooming'. They should point out how to maintain borders even when having an intense personal instructor/athlete relationship. Attention should also be devoted to the issue of people with malicious intent who increasingly falsely accuse others of sexual offences and can cause irreparable damage to a person's reputation and career. Therefore, awareness statements should also include a clause which indicates that those making false complaints of sexual harassment against someone equally will be severely penalized if proven.

A serious effort should be made to integrate lectures and discussions back in jū $\bar{u} \bar{o}$ as these existed under Kanō through involvement of people who have the intellectual know-how. Jüdō and $j \bar{u} d \bar{o}$ federations should learn to be self-critical rather than engage in muscle flexing, and they should show openness towards learning from experts irrespective of nationality, race, creed, gender or sexual preference.

$J \bar{u} d \bar{o} k a$ and $j \bar{u} d \bar{o}$ instructors should fully realize the potential consequences of the ongoing eroticization of $j \bar{u} d \bar{o}$. There is no need to be morally conservative or Victorian, but there is a need for mentorship and insight into the potential consequences for those who may have a less stable economic, family, partner relationship or sexuality. Self-control by the jūdo community in a constructive way can easily achieve that just like any teacher may need to step in if kids play takes a turn for the worse.

\section{Notes}

Note 1: Japanese names in this paper are listed by family name first and given name second, as common in traditional Japanese usage and to maintain consistency with the order of names of Japanese historic figures.

Note 2: For absolute rigor, long Japanese vowel sounds have been approximated using macrons (e.g. Kōdōkan) in order to indicate their Japanese pronunciation as closely as possible. However, when referring to or quoting from Western literature, the relevant text or author is cited exactly as per the original source, with macrons used or omitted accordingly. 


\section{References}

Anderson, G. (2008). Judo official accused of molestation. Almost 30 years ago, teens said Middletown businessman abused, drugged them. The Press Democrat, 29 July 2008. Retrieved April 25, 2012]. Retrieved from: http://www.pressdemocrat.com/article/ 20080729/NEWS/807290344.

Andō, Y. (2013). Interview with Kaori Yamaguchi: Revival of 'respect' needed to mend judo's ways. The Asahi Shimbun, 15 February, 2013. Retrieved April 15, 2013. Retrieved from: http://ajw.asahi.com/ article/sports/topics/AJ201302150007.

Anonymous (2004a). Celstraf geëist tegen judoleraar wegens ontucht [Jail time demanded for jūdō instructor for indecency]. ANP, 6 July, 2004. Retrieved January 23, 2012. Retrieved from: Pedofilie.nl: http:// www.pedofilie.nl/node/141 [in Dutch].

Anonymous (2009a). Der stumme Schrei der jungen Sportler [The silent cry of the young sporter]. Nürnberger Nachrichten online, 22 October, 2009. Retrieved January 25, 2012. Retrieved from: URL: http://www. nordbayern.de/nuernberger-nachrichten/nuernberg/ der-stumme-schrei-der-jungen-sportler-1.591483 [in German].

Anonymous (2006). Former Canadian judo coach sentenced in sex case. Réseau Canoë, Montreal, 17 March, 2006. Retrieved January 28, 2012. Retrieved from: http://slam.canoe.ca/ Slam/OtherSports/2006/03/17/1493124.

Anonymous (2002). Herman Raucher Interview (extended). [article online] May 2002. Retrieved January 23, 2012]. Retrieved from: http://web.tcpalm.com/specialreports/ summerof42/raucher.html.

Anonymous (2009b). Ik dacht: handtastelijkheden horen erbij [I thought: sexual harrassment is part of it]. Algemeen Dagblad Sportwereld, 28 August, 2009. Retrieved January 23, 2012]. Retrieved from: http:// www.ad.nl/ad/nl/1001/Sportwereld/article/detail/2054417/ 2009/08/28/lsquo-Ik-dacht-handtastelijkheden-horen-erbij.dhtml [in Dutch].

Anonymous (2007a). Ja ik heb een lief van 16 jaar. En dan ? [Yes, I have a lover who is 16 years old. So what ?]. Gazet van Antwerpen, 6 December 6, 2007. Retrieved January 23, 2012]. Retrieved from: http:// www.gva.be/arch/ja-ik-heb-een-lief-van-16-jaar-en-dan. aspx [in Dutch].

Anonymous (2013a). JOC report brands judo coach sadist. The Japan Times, 17 March, 2013. Retrieved March 17, 2013. Retrieved from: http://www.japantimes.co.jp/news/2013/03/ 18/national/joc-reportbrands-judo-coach-sadist/\#.UUYBUzfJKdE.

Anonymous. (2007b). Judo coach arrested for $2^{\text {nd }}$ time. WDTN-TV, Dayton, OH, 20 July, 2007. Retrieved July 28, 2007. Retrieved from: http://www.msnbc.msn.com/id/19871477.

Anonymous (2007c). Judo instructor accused of inappropriate relationship with student. WHIOTV, Xenia, OH, 10 May, 2007. Retrieved May 12, 2007. Retrieved from: http://www.whiotv.com/news/13292122/ detail.html.

Anonymous. (2009c). Judo instructor accused of sodomizing teen. KRCA.com, 28 May, 2009c. Retrieved April 28, 2010. Retrieved from: http://www.kcra.com/news/19594340/detail. html.

Anonymous. (2007d). Judo instructor pleads guilty to sex with teen. WHIOTV, 9 November, 2007. Retrieved November 9, 2007. Retrieved from: http://www.whiotv.com/news/news/ judo-instructor-pleadsguilty-to-sex-with-teen/nD9mf/l.

Anonymous (2007e). Judo instructor pleads guilty to sex with teen. Jill Del Greco reports on angry reaction after plea [Video clip]. WHIOTV, 9 November, 2007. Retrieved November 9, 2007. Retrieved from: http://mfile.akamai.com/12937/wmv/vod.ibsys.com/2007/1109/14554693.200k.asx.

Anonymous (2004b). Judoleraar de cel in. Jaar plus zes maanden voorwaardelijk na ontucht met jongens [Jūdō instructor to jail. One year plus six months of probation after indecency with boys]. Het Parool, 13 July, 2004. Retrieved January 23, 2012. Retrieved from: Pedofilie.nl: http://www.pedofilie.nl/ node/159 [in Dutch].

Anonymous (2010). Judotrainer zu langer Haftstrafe verurteilt [Judo coach sentenced to long prison sentence]. Stern.de, 7 January, 2010. Retrieved January 25, 2012. Retrieved from: http://www.stern.de/panorama/ kindesmissbrauch-judotrainer-zu-langer-haftstrafe-verurteilt-1534068.html [in German]. 
Anonymous (2004c). Ontuchtzaak judoleraar groeit [Indecency case judo instructor growing. De Volkskrant 2 April 2004. Retrieved January 23, 2012. Retrieved from: http://www.volkskrant.nl/vk/nl/2844/Archief/ archief/article/detail/704480/2004/04/02/Ontuchtzaak-judoleraar-groeit.dhtml [In Dutch].

Anonymous. (2008). Tom Boonen en Sophie Van Vliet uit elkaar. [Tom Boonen and Sophie Van Vliet broke up]. Het Laatste Nieuws, 18 January, 2008. Retrieved January 23, 2012]. Retrieved from: http://www. hln.be/hln/nl/952/home/article/detail/137863/2008/01/18/Tom-Boonen-en-Sophie-Van-Vliet-uit-elkaar. dhtml [in Dutch].

Anonymous (2012). Three high school students died in school judo activities in 2011. Japan Judo Accident Victims Association, 2012. Retrieved January 23, 2012. Retrieved from: http://judojiko.net/eng/ news/185.html.

Anonymous (2013). 3 Jaar cel voor judoleraar Ruurlo [3 Years in prison for Ruurlo jūdō instructor]. Omroep Gelderland, 25 January 2013. Retrieved January 31, 2013. Retrieved from: http:/www.omroepgelderland.nl/web/Nieuws-1/1993917/3-jaar-cel-voor-judoleraar-Ruurlo.htm\#.UT0jiDfJIg8 [in Dutch].

Anonymous (2013c). JOC cuts judo funding after physical abuse probe. Japan Today; 20 March 2013. Retrieved March 20, 2013. Retrieved from: http://www.japantoday.com/category/sports/view/joccuts-judo-funding-after-physical-abuse-probe.

Anonymous (2014). Ermittlungen gegen Seisenbacher bald abgeschlossen [Investigation against Seisenbacher soon completed]. Wiener Zeitung, 11 June, 2014. Retrieved June 15, 2014. Retrieved from: http:// www.wienerzeitung.at/nachrichten/oesterreich/chronik/637069_Ermittlungen-gegen-Seisenbacherbald-abgeschlossen.html [in German].

Associated Press (2013). Japan Olympic judoka Masato Uchishiba sentenced to 5 years in prison for 2011 rape of student. The Washington Post, 2 February, 2013.

Baxter, K. (2012). Judo's Kayla Harrison finds sanctuary - and perhaps Olympics gold. Chicago Tribune \& Los Angeles Times, 26 April 2012. Retrieved May 23, 2012. Retrieved from: http://www.chicagotribune.com/sports/la-sp-oly-judo-kayla-harrison-20120427,0,4419736.story or http://articles.latimes. com/2012/apr/26/sports/la-sp-oly-judo-kayla-harrison-20120427.

BBC News. (2008). Sex assault judo coach is jailed. BBC News, 14 February 2008. Retrieved February 14, 2008]. Retrieved from: http://news.bbc.co.uk/2/hi/uk_news/wales/south_west/7245386.stm.

Bennett, A. (Ed. \& Transl.) (2009). Women's Judo. In Jigoro Kano and the Kodokan. An innovative response to modernization (pp. 137). Tōkyō: Kōdōkan Jūdō Institute.

Brackenridge, C.H. (2004). Burden or benefit? The impact of Sport Scotland's child protection programme with governing bodies of sport. Research Report 94, Edinburgh: Sport Scotland.

Brackenridge, C. H. (2000). Harassment, sexual abuse, and safety of the female athlete. Clinics in Sports Medicine, 19 (2), 187-198.

Brackenridge, C. H. (1999). Managing myself: investigator survival in sensitive research. International Review for the Sociology of Sport, 34 (4), 399-410.

Brackenridge, C. H. (1997). Sexual harassment and sexual abuse in sport. In G. Clarke \& B. Humberston (Eds.), Researching Women in Sport (pp. 126-141). London: Macmillan.

Brackenridge, C. H. (2002). So what? Attitudes of the voluntary sector towards child protection in sports clubs. Managing Leisure - An International Journal, 7, 2, 103-124.

Brackenridge, C.H., Bishopp D., Moussali S., \& Tapp J. (2008). The characteristics of sexual abuse in sport: A multidimensional scaling analysis of events described in media reports. International Journal of Sport and Exercise Psychology, 16 (4) (Special Issue: Abuse and Harassment in Sport Implications for the Sport Psychology Profession), 385-406.

Brackenridge, C. H., Fasting, K., Kirby, S., \& Leahy T. (no date). Protecting children from violence in sport: a review with a focus on industrialized countries. Florence, Italy: UNICEF Innocenti Research Centre. IRC Stock No. 590U. Retrieved February 14, 2012. Retrieved from: http://www.unicef-irc.org/ publications/pdf/violence_in_sport.pdf. 
Brackenridge, C. H., Fasting, K., Kirby, S., Leahy, T., Parent, S., \& Svela Sand, T. (2010). The place of sport in the UN study on violence against children. Florence, Italy: UNICEF Innocenti Research Centre, IRC Stock No. 595U, Innocenti Discussion Papers, IDP 2010-01. [retrieved February 14 ${ }^{\text {th }}, 2012$ ]. Retrieved from: URL: http://www.unicef-irc.org/cgi-bin/unicef/Lunga.sql?ProductID=593.

Brasor, Ph. (2011). Wrestling with the serious issue of rape. The Japan Times, 18 December 2011. Retrieved January 23, 2012. Retrieved from: http://www.japantimes.co.jp/text/ fd20111218pb.html.

Bringer, J. D., Brackenridge, C. H., \& Johnston, L. H. (2002). Defining appropriateness in coach-athlete sexual relationships: The voice of coaches. Journal of Sexual Aggression, 8 (2), 83-98.

Bringer, J. D., Brackenridge, C. H., \& Johnston, L. H. (2006). Swimming coaches' perceptions of sexual exploitation in sport: a preliminary model of role conflict and role ambiguity. The Sport Psychologist, 20, 465-479.

Bringer, J. D., Brackenridge, C. H., Johnston, L. H. (2001). The name of the game: A review of sexual exploitation of females in sport. Current Women's Health Reports, 1 (3), 225-231.

Buckle, M. (2009, June). Preventing child abuse in judo. Growing Judo, 11-20. Retrieved January 23, 2012. Retrieved from: http://www.usja-judo.org/growing-judo/.

Buckler, Ch. (2012). Action needed to protect kids in sport from sex abuse. BBC News - Education \& Family, 10 July 2012; ca. 2 pages. Retrieved July 10, 2012. Retrieved from: URL: http://www.bbc.co.uk/ news/education-18746389.

Burke, M. (2010). 108 School judo class deaths but no charges, only silence. The Japan Times, 26 August, 2010.

Caligiuri, C. (2011). Youth coach \& his wife plead not guilty: Curtis \& Crystal Rogers accused of molesting kids, 9 November 2011. Retrieved January 28, 2012. Retrieved from: http://www.wpri.com/dpp/news/ local_news/providence/providence-coach-and-wife-plead-to-molestation-charges.

Casado, J. E., \& Villamón, M. (2009). La utopiá educativa de Jigoro Kano: El judo Kodokan [The educational utopia of Jigorō Kanō: Kōdōkan jūdō]. Revista de História do Esporte, 2 (1), 1-40 [in Spanish].

Cayleff, S. (1995). Babe: The life and legend of Babe Didrikson Zaharias. Urbana, IL: University of Illinois Press.

Cazeneuve, B. (2012). America's first family of judo offers rising star Kayla Harrison a safe haven. Sports Illustrated, 116 (10), 18.

Cense, M., \& Brackenridge, C. H. (2001). Temporal and developmental risk factors for sexual harassment and abuse in sport. European Physical Education Review, 7 (1), 61-79.

Connolly, W. B., \& Marshall, A. B. (1989). Sexual harassment of university or college students by faculty members. Journal of College and University Law, 15, 381-403.

Curtis, A. (2009). What happened to Alvin Miyatake? Judoforum, 14 October 2009. Retrieved January 25, 2012. Retrieved from: http://judoforum.com/index.php?/topic/40983.

d'Arripe-Longueville, F., Fournier, J. F., \& Dubois, A. (1998). The perceived effectiveness of interactions between expert French judo coaches and elite female athletes. The Sport Psychologist, 12, 317-332.

De Crée, C., \& Jones, L. C. (2011). Kōdōkan jūdō’s inauspicious ninth kata: The Joshi goshinhō — Selfdefense methods for females (Part 1). Archives of Budo, 7 (3), OF105-123.

De Crée, C. (2005). Health and training concerns of elite female judoists (Invited presentation). USA Judo National Coaching Conference, Olympic Training Center, Colorado Springs, CO, November 5, 2005.

De Havensloods, A. (2011). Judoleraar zou ontuchtpleger zijn [Jūdō instructor alleged lecher]. Dé Weekkrant.nl, 22 December 2011. Retrieved January 28, 2012. Retrieved from: http://www.deweekkrant. nl/artikel/2011/december/22/judoleraar_zou_ontuchtpleger_zijn_159 [in Dutch].

De Havensloods, A. (2012). Judoleraar mag actief blijven [Jūdō instructor allowed to remain active]. Dé Weekkrant.nl, 19 July 2012. Retrieved November 28, 2012. Retrieved from: http://www.deweekkrant. nl/artikel/2012/juli/19/judoleraar_mag_actief_blijven_ondanks_ontucht [in Dutch].

De Stentor (2012). Leo Buitink opgepakt voor misbruik [Leo Buitink arrested for abuse]. De Stentor, 9 October 2012. Retrieved December $10^{\text {th }}$, 2012. Retrieved from: http://www.destentor.nl/regio/lochem/ leo-buitink-opgepakt-voor-misbruik-1.3513310 [in Dutch]. 
Diamond, M., \& Uchiyama, A. (1999). Pornography, rape and sex crimes in Japan. International Journal of Law and Psychiatry, 22 (1), 1-22.

Dussault, J. (2006). Sylvain Hébert risque l'emprisonnement. Réseau Canoë, Montreal, 14 March 2006. Retrieved January 28, 2012. Retrieved from: http://fr.canoe.ca/sports/nou velles/archives/2006/03/20060314-092000.html [in French].

Endedijk, B., \& van Steenbergen, E. (2012). 'Foute' jeugdtrainer blijft uit beeld, nog geen zwarte lijst ontuchtplegers ['Wrong' youth instructor remains out of view, still no sex offender blacklist]. NRC Handelsblad, 2 June 2012: 6. Retrieved April 28, 2012. Retrieved from: http://digitaleeditie.nrc.nl/ digitaleeditie/NH/2012/5/20120602 /1_06/full_page_1_06.html[in Dutch].

Ensslin, J. C. (2010a). Olympic athlete acquitted of rape charge. Jury finds him guilty of 2 misdemeanors. The Gazette, Colorado Springs, CO, 7 October 2010. Retrieved January 23, 2012]. Retrieved from: http://www.gazette.com/articles/olympic-105955-acquitted-downtown.html.

Ensslin, J. C. (2010b). Teen describes alleged rape in trial of Olympic judo athlete. The Gazette, Colorado Springs, CO, 9 September 2010. Retrieved January 23, 2012. Retrieved from: http://www.gazette.com/ articles/judo-105510-olympic-athlete.html.

European Federation for Sport Psychology (FEPSAC). (2002). Sexual exploitation in sport. Position statement No. 6. Retrieved January 23. Retrieved from: http:/www.fepsac.com/index.php/ activities/ position_statements.

Fasting, K., \& Brackenridge, C. H. (2009). Coaches, sexual harassment and education. Sport, Education and Society, 14 (1), 21-35.

Fasting, K., Brackenridge, C. H., \& Kjølberg, G. (2011). Using court reports to enhance knowledge of sexual abuse in sport. London: Brunel University, School of Sport and Education Research Papers. Retrieved January 23, 2012. Retrieved from: http://bura.brunel.ac.uk/ handle/2438/5001.

Fasting, K., Brackenridge, C., \& Knorre, N. (2010). Performance level and sexual harassment prevalence among female athletes in the Czech Republic. Women in Sport \& Physical Activity Journal (WSPAJ), $19,26-32$.

Fasting, K., Brackenridge, C. H., Miller, K. E., \& Sabo, D. (2008). Participation in college sports and protection from sexual victimization. International Journal of Sport and Exercise Psychology, 16 (4), 427- 441.

Fasting, K., Brackenridge, C. H., \& Walseth, K. (2002). Consequences of sexual harassment in sport for elite female athletes. International Research and Policy Perspectives, 8 (2) (Special issue: Sexual Harassment and Abuse in Sport - International Research and Policy Perspectives), 37-48.

Federal Bureau of Investigation (FBI). (2007). Greene county judo instructor pleads guilty to sex with teenage student during foreign travel. Federal Bureau of Investigation, Cincinnati Division, Department of Justice, Press Release. Retrieved January 20, 2008. Retrieved from: http://cincinnati.fbi.gov/doj/ pressrel/2007/ci110907.htm.

Forgrave, R. (2012). Harrison overcomes past sexual abuse. Fox Sports, 7 May 2012. Retrieved January 23, 2012. Retrieved from: http://msn.foxsports.com/olympics/judo/story/Judo-Kayla-Harrison-overcomessexual-abuse-and-aims-for-Olympic-Glory-at-London-2012.

Gomez, B. (2011). Olympic judo player gets 60 days on oral sex charges. The Gazette, 8 February 2011. Retrieved January 23, 2012. Retrieved from: http://www.gazette.com/articles/ sex-112514-yearsoral.html.

Gray, H. (2008). Rape and Sexual Assault in Japan: Potential Gender Bias in Pre-Trial Pro-cedures. Reinvention A Journal of Undergraduate Research, 1 (1) [article online] Retrieved February 8, 2011. Retrieved from: http://www2.warwick.ac.uk/go/reinvention journal/volume1 issue1/gray.

Guérandel, C., \& Mennesson, Ch. (2007). Gender construction in judo interactions. International Review for the Sociology of Sport, 42 (2), 167-186.

Halbert, C. (1997). Tough enough and woman enough: Stereotypes, discrimination, and impression management among women professional boxers. Journal of Sport and Social Issues, 21 (1), 7-36.

Hall, R.C., \& Hall, R. C. (2007). A profile of pedophilia: definition, characteristics of offenders, recidivism, treatment outcomes, and forensic issues. Mayo Clinic Proceedings, 82 (4), 457-471. 
Hayez, J.Y., Vervier, J.F., \& Charlier, D. (1994). De la crédibilité des allégations des mineurs d'âge en matière Vol. 9, No. 2, 2015

d'abus sexuel [Credibility of allegations of under age minors regarding sexual abuse]. La Psychiatrie de l'enfant, 37, (2), 361-394 [in French].

Holden, M. (2012). Judo: Harrison savors rise from victim to champion. Yahoo! News; 3 August 2012, ca. 2 pages. Retrieved August 3, 2012. Retrieved from: http://news.yahoo.com/ harrison-savors-risevictim-champion-1947241.

International Olympic Committee (IOC). (2007). Consensus statement: Sexual harassment and abuse in sport. Press Release PR-05-2007, 8 February, 2007. Retrieved, January 23, 2012. Retrieved from: http:// www.olympic.org/Documents/Reports/EN/en_report_1125. pdf.

Japanese Ministry of Justice. (2007). Penal code (Keihō 刑法), Law number: Act No. 45 of 1907, Amendment: Act No. 54 of 2007, Dictionary Ver: 1.0, Translation date: April 1, 2009. Retrieved from: http:// www.japaneselawtranslation.go.jp/law/detail/?ft $=2 \&$ re $=02 \& \mathrm{dn}=1 \& \mathrm{yo}=$ penal $+\operatorname{code} \& \mathrm{x}=0 \& \mathrm{y}=0$ $\& \mathrm{ky}=\&$ page $=1$.

Jiji Press. (2013). Judo gold medalist Uchishiba gets 5-year sentence for rape. Daily Yomiuri Online, 2 February 2013. Retrieved, February 2, 2013]. Retrieved from: http://www.yomiuri.co.jp/dy/national/ T130201005380.htm.

Jordan, R. (2012). Livermore man sentenced to prison for sex with teen girl. San Jose Mercury News, 9 July, 2012. Retrieved July 10, 2012. Retrieved from: http://www.mercurynews. com/ci_21039222/ livermore-man-sentenced-prison-sex-teen-girl

Kanō, C. (嘉納知古霊) (2007). Blacklisted/expelled members Should NGBs publish lists with blacklisted members? JudoForum, 3 August, 2007, ca. 21 pages. Retrieved January 23, 2012]. Retrieved from: http://judoforum.com/index.php?/topic/18783-blacklisted expelled-mem.

Kanō, J. (2006). Mind over Muscle: Writings from the Founder of Judo. N. Murata (Ed.) \& N.H. Ross (Transl.). Tōkyō: Kōdansha International.

Kanō, J. (嘉納治五郎) (1917). Onore no tame ka yo no tame ka (己の為ためか世 のためか) [To one’s own usefulness and that of the world]. Jūdō (柔道) 3 (1) [in Japanese].

Kanō, J. (嘉納治五郎) (1911). Seinen shūyō kun (青年修養訓) [The teaching of young man’s moral selfimprovement]. Tōkyō: Tōbunkan (同文官) [in Japanese].

Kanō, J. (嘉納治五郎) (1926). Sei-ryoku zen’yō ji-ta kyō-ei ni kan suru shitsumon ni kotau (精力善用己 自他共栄に関する質問にこたう) [Questions and answers regarding the efficient use of energy and mutual prosperity]. Sakkō (作興), 5 (6), 71-75 [in Japanese].

Kirby, S., Greaves, L., \& Hankivsky, O. (2000). The Dome of Silence: Sexual harassment and abuse in sport. London: Zed Books.

Landgericht Passau. (2009). Presseerklärung des Landgerichts Passau (14/09) vom 21.12.2009: Missbrauchsfälle im Judoclub Passau [Press release from the Passau District Court from December 21, 2009: Abuse case in Passau Judo Club]. Retrieved January 25, 2012. Retrieved from: http://www.justiz.bayern.de/ gericht/lg/pa/presse/archiv/2009/02363/ [in German].

Laufer, S. (2011). Die große Stille. El Faro (Verein zur Hilfe und Unterstützung von Opfern sexuellen Missbrauchs und Gewalt e.V.) [The great silence. El Faro (Association for help and support to victims from sexual abuse and violence)]; 21 June, 2011. Retrieved January 25, 2012. Retrieved from: http:// www.elfaro.de/Geschichten/Sexuelle_Gewalt_in_Sportvereinen_-_Simon_Laufer.pdf [in German].

Lenskyj, H. J. (1992). Unsafe at home base: Women's experiences of sexual harassment in university sport and physical education. Women in Sport and Physical Activity Journal, 1 (1), 19-33.

Ley, R. (1998). Sexual harassment in the dojo: can it be controlled ? Karate Kung Fu Illustrated, 29 (6), $56-58 \& 64-65$.

McCarthy, R. (2009a). Judge: Recorded calls sealed molester's fate. 25 March 2009. Retrieved January 28, 2012]. Retrieved from: http://www.appeal-democrat.com/articles/leonard-93109-boy-years.html.

McCarthy, R. (2009b). Photos of naked boys on judo coach's laptop. Appeal Democrat, 10 June 2009. Retrieved January 28, 2012. Retrieved from: http://www.appeal-democrat.com/news/boys-78431-nakedleonard.html. 
McCurry, J. (2013). Japanese women's judo coach resigns over claims he abused athletes. The Guardian, 1 February 2013.

Meloy, J. R. (2002). The polymorphously perverse psychopath: Understanding a strong empirical relationship. Bulletin of the Meninger Clinic, 66 (3), 273-289.

National Sexual Violence Resource Center (SVRC). (2005). Preventing child sexual abuse: a national resource directory and handbook. Enola, PA: National Sexual Violence Resource Center.

Parshad, S. P. (2012). Rape case: Police fail to arrest absconding judo coach. Hindustan Times, 26 June 2012; ca. 2 pages. Retrieved June 28, 2012]. Retrieved from: http://www.hindustantimes.com/ StoryPage/ Print/879048.aspx.

Pilon, C.È. (2005). L'entraîneur du Club de judo de Varennes plaide coupable - Infraction à caractère sexuel [The coach of the Judo Club of Varennes pleads guilty - sexual abuse]. La Seigneurie, Les Hebdos Régionaux - Actualités, 20 August 2005. Retrieved January 28, 2012. Retrieved from: http:// www.hebdosregionaux.ca/monteregie/main+fr+01_300+L_entraineur_du_Club_de_judo_de_Varennes_plaide_coupable.html?ArticleID=416769 [in French].

PTI (2012). Judo player accuses coach of raping her. The Times of India, 27 June 2012; ca. 2 pages. Retrieved June 28, 2012]. Retrieved from: http://timesofindia.indiatimes.com/sports/more-sports/others/Judoplayer-accuses-coach-of-raping-her/articleshow/ 14435214.cms.

Rhode Island State Police. (2011). Press Releases: RISP Computer Crimes Unit/Internet Crimes Against Children Task Force arrests youth football coach for sexual assault \& child molestation, 24 June 2011. Retrieved January 28, 2012. Retrieved from: http://www.ri.gov/press/view/14144

Rodriguez, J. H. (2009). Letter to Jerry Hays. USA Judo, 10 March 2009.

Siekmann, R. C. R., \& Soek, J. (2001). Arbitral and disciplinary rules of international sports organizations. The Hague: T.M.C. Asser Press.

Singh, J. (2012). National level judo player raped by coach at training camp. Punjab Newsline, 27 June 2012; ca. 2 pages. Retrieved June 27, 2012]. Retrieved from: http://www.punjabnewsline.com/content/ national-level-judo-player-raped-coach-training-camp/49658.

Svinth, J. R. (2001). The Fairchild air force base judo club, 1951-1960. Journal of Non-lethal Combatives February 2001. Retrieved January 23, 2012]. Retrieved from: URL: http://ejmas.com/jnc/jncart svinth_0201.htm.

Thamel, P. (2008a). Claims of molestation resurface for judo official. New York Times, 26 July 2008. Retrieved January 25, 2012. Retrieved from: http://www.nytimes.com/2008/07/26/ sports/olympics/26judo. html?_r=1\&pag.

Thamel, P. (2008b). Judo official resigns post, but inquiry may continue. New York Times 27 July 2008. Retrieved January 25, 2012]. Retrieved from: http://www.nytimes.com/2008/ 07/27/sports/ olympics/27olympics.html.

The Associated Press. (2012). Ex-judo coach facing 3 years for teen sex. Contra Costa Times, 25 April 2012. [Retrieved April 25, 2012]. Retrieved from: http://www.contracostatimes. com/ci_20476125/ ex-judo-coach-facing-3.

The Japan Times Editorials. (2013). Judo culture needs to change. The Japan Times, 14 February 2013.

The People v. David Gerald Leonard. (2011). Court of Appeal of the State of California, Third Appellate District, 13 May 2011. Retrieved January 28, 2012. Retrieved from: http://ca.findacase.com/research/ wfrmDocViewer.aspx/xq/fac.20110513_0003713.CA.htm/qx.

Thissen, P. (2012). Former Livermore judo coach pleads no contest to sex crime. Mercury News, San Jose, CA, 24 April 2012. Retrieved April 25, 2012. Retrieved from: http://www.mercurynews.com/breakingnews/ci_20469303.

Toftegaard Nielsen, J. (2001). The forbidden zone: Intimacy, sexual relations and misconduct in the relationship between coaches and athletes. International Review for the Sociology of Sport, 36 (2), 165-183. 
Towne, S. (2012). Youth coach sentenced for sex crimes. WPRI.com Eyewitness news, 12 July 2012. Retrieved July 14, 2012. Retrieved from: URL: http://www.wpri.com/dpp/news/ local_news/blackstone/ pawtucket-youth-football-coach-curtis-rogers-sentenced-for-sex-crimes.

United States Department of Justice (USDOJ). (2007). Greene county judo instructor pleads guilty to sex with teenage student during foreign travel. Department of Justice, United States Attorney Gregory G. Lockhart, Southern District of Ohio, Press Release, 9 November 2007. Retrieved January 20, 2008. Retrieved from: http://www.usdoj.gov/ usao/ohs.

United States Department of Justice (USDOJ). (2012). Dru Sjodin National Sex Offender Public Website (NSOPW). Office of Sex Offender Sentencing, Monitoring, Apprehending, Registering, and Tracking (SMART). Retrieved January 24, 2012. Retrieved from: URL: http://www.usdoj.gov/usao/ohs http:// www.nsopw.gov/Core/Portal.aspx.

Van Corven, T. (1997). Graaiende ex-coach: topsport is misvorming [Grabbling ex-coach: top sport is distorting]. Trouw, 10 July 1997; ca. 1 1/4 pages. Retrieved January 23, 2012]. Retrieved from: http://www. trouw.nl/tr/nl/5009/Archief/archief/article/detail/2570947/1997/07/10/Graaiende-ex-coach-topsportis-misvormend.dhtml [in Dutch].

Van Der Ziel, A. (1996). Judobond wist al jaren van machtsmisbruik en seksuele intimidatie Ooms [Judo federation knew since years of the abuse of power and sexual harassment Ooms]. Trouw 5009, 11 November 1996 [in Dutch].

Van Wissen, H. (1996a). Judokas klagen Ooms aan om anderen te beschermen [Jūdōka file complaints against Ooms to protect others]. Volkskrant, 23 February 1996 [in Dutch].

Van Wissen, H. (1996b). Ooms trekt zich terug uit de judowereld [Ooms withdraws himself from the judo world]. Volkskrant, 2 March 1996 [in Dutch].

Verspeek, P. (2011). Van misbruik verdachte judoleraar slachtoffer complot [Jūdō instructor suspected of sexual abuse, victim of conspiracy]. Rijnmond, 15 December 2011. Retrieved January 23, 2012]. Retrieved from: RTV Rijnmond.nl: http://www.rijnmond.nl/nieuws/ 15-12-2011/van-misbruik-verdachtejudoleraar-slachtoffer-complot [in Dutch].

Verspeek, P. (2012a). Judoleraar veroordeeld voor ontucht [Jūdō instructor convicted for indecency]. Rijnmond, 11 July 2012. Retrieved November 23, 2013]. Retrieved from: RTV Rijnmond.nl: http://www. rijnmond.nl/nieuws/11-07-2012/judoleraar-veroordeeld-voor-ontucht [in Dutch].

Verspeek, P. (2012b). Van misbruik verdachte judoleraar komt voorlopig vrij [Jūdō instructor suspected of sexual abuse temporarily released]. Rijnmond, 8 March 2012. Retrieved January 23, 2012. Retrieved from: RTV Rijmond.nl: http://www.rijnmond.nl/nieuws/08-03-2012/van-misbruik-verdachte-judoleraar-komt-voorlopig-vrij [in Dutch].

Verspeek, P. (2012c). Zes jaar cel geëist tegen judoleraar Ijsselmonde [Six years demanded for Ijsselmonde jūdō instructor]. Rijnmond, 26 June 2012 [retrieved November 23, 2013]. Retrieved from: RTV Rijnmond.nl: http://www.rijnmond.nl/nieuws/27-06-2012/zes-jaar-cel-geeist-tegen-judoleraar-ijsselmonde [in Dutch].

Vlaamse Overheid [Flemish Government]. (2012). Engagementsverklaring ter bescherming van de seksuele integriteit van de minderjarige in de sportsector [Declaration of Commitment to protect the sexual integrity of minors in sports]. Brussels, 29 February 2012. [Retrieved 2012]. Retrieved from: http://www. cjsm.vlaanderen.be/gezondsporten/evs/ 20120229 engagementsverklaringsportsector.pdf [In Dutch].

Vlaamse Regering [Flemish Government]. (2011). Medeling aan de leden van de Vlaamse Regering inzake de aanpak van geweld op kinderen en, in het bijzonder, kindermisbruik [Communication to the members of the Flemish Government concerning the handling of violence towards children and, in particular, child abuse], 23 September 2011, \#VR 20112309 MED.0456. Retrieved, January 23, 2012. Retrieved from: http://www.cjsm. vlaanderen.be/gezondsporten/evs/20110923mededelingVR.PDF [In Dutch].

Weiss, K. (2002). Authority as coercion: when authority figures abuse their positions to perpetrate child sexual abuse. Journal of Child Sexual Abuse, 11 (1), 27-51.

Whiting, R. (2013a). Corporal punishment has long history in Japanese sports (Part 1). The Japan Times, 26 May 2013 [retrieved June 2, 2013]. Retrieved from: http://www.japantimes. co.jp/sports/2013/05/26/ baseball/corporal-punishment-has-long-history-in-japanese-sports/\#.UatSzdhmNr5 
128 Whiting, R. (2013b). Severe sports training methods became taibatsu in time (Part 2). The Japan Times, 02 June 2013 [retrieved June 2, 2013]. Retrieved from: http://www.japantimes. co.jp/sports/2013/06/02/ baseball/severe-sports-training-methods-became-taibatsu-in-time /\#.Uati8thmNr7

Westlake, A. (2012). Prosecutors seek 5 year sentence for Olympic judo champ Uchishiba. The Japan Daily Press, 28 December 2012.

Westlake, A. (2013). Tokyo court finds Olympic judo champion Uchishiba guilty of rape, gives 5 year prison sentence. The Japan Daily Press, 1 February 2013.

Wright Dziech, B., \& Winer, L. (1990). The lecherous professor. Sexual harassment on campus (pp. 1-288). Champaign, IL: University of Illinois Press.

Advised by A.R. Barros,

Emeritus Professor, Coimbra, Portugal

Received: May 13, 2013

Accepted: February 12, 2014

Carl De Crée Senior Research Professor of Exercise Science \& Sports Medicine, Medical Sexologist

\& Japanologist, EJU Level-6 High-Performance Jūdō Coach

Chief-Instructor, Royal Jūdō \& Karate Academy Bushidō-Kwai Center for Sports

Medicine, P.O. Box 125, B-2800 Malines, Belgium.

Fax: +44-870-762-1701.

E-mail: prof.cdecree@earthlink.net

Website: http://www.carldecree.net 